\title{
Selection of benthic habitat by yellow-phase American eels (Anguilla rostrata)
}

\author{
Melissa A. Braham \\ West Virginia University
}

Follow this and additional works at: https://researchrepository.wvu.edu/etd

\section{Recommended Citation}

Braham, Melissa A., "Selection of benthic habitat by yellow-phase American eels (Anguilla rostrata)" (2012). Graduate Theses, Dissertations, and Problem Reports. 215.

https://researchrepository.wvu.edu/etd/215

This Thesis is protected by copyright and/or related rights. It has been brought to you by the The Research Repository @ WVU with permission from the rights-holder(s). You are free to use this Thesis in any way that is permitted by the copyright and related rights legislation that applies to your use. For other uses you must obtain permission from the rights-holder(s) directly, unless additional rights are indicated by a Creative Commons license in the record and/ or on the work itself. This Thesis has been accepted for inclusion in WVU Graduate Theses, Dissertations, and Problem Reports collection by an authorized administrator of The Research Repository @ WVU. For more information, please contact researchrepository@mail.wvu.edu. 
Selection of benthic habitat by yellow-phase American eels (Anguilla rostrata)

Melissa A. Braham

Thesis submitted to the

Davis College of Agriculture, Natural Resources, and Design

at West Virginia University

in partial fulfillment of the requirements

for the degree of

Master of Science

in

Wildlife and Fisheries Resources

Stuart A. Welsh, Ph.D., Chair

Patricia M. Mazik, Ph.D.

David R. Smith, Ph.D.

Division of Forestry and Natural Resources

Morgantown, WV

2012

Keywords: American eel (Anguilla rostrata), yellow-phase, habitat use, habitat selection 


\begin{abstract}
Selection of benthic habitat by yellow-phase American eels (Anguilla rostrata) Melissa A. Braham
\end{abstract}

This thesis examines habitat preference of yellow-phase American eels (Anguilla rostrata) and relationships between age and length with that preference. The thesis is comprised of two chapters: (1) an introduction and literature review on American eel life history, their habitat selection, and the study of resource selection, and (2) an experimental study of yellowphase American eel habitat preference and relationships between preference and age and length. Given widespread habitat alteration of North American rivers, an understanding of the use and selection of habitat is important to conservation and management of the American eel. Yellowphase American eels are often considered as habitat generalists, in part, because of their occurrence across a wide range of habitat types, but few experimental studies have examined microhabitat selection. In a laboratory experiment, I quantified microhabitat use of small yellowphase American eels $(\mathrm{n}=130,224-338 \mathrm{~mm}$ TL) conditional on five benthic substrate types common to many rivers within the geographic range of the American eel. During nine, 4-day trials replicated with three aquaria, American eels were given a choice to burrow into five equally available benthic substrates: cobble $(90-256 \mathrm{~mm})$, gravel $(4-16 \mathrm{~mm})$, sand $(0.125-1$ $\mathrm{mm}$ ), silt/clay $(<0.0625 \mathrm{~mm})$, and leaf pack. Five American eels were used per aquaria for each trial, and individuals were used one time only. All eels were injected with PIT tags prior to the study, which allowed for determination of lengths and otolith-based ages of each individual following each trial. Leaf pack was selected with a significantly higher probability than other substrates (63 of 130 individuals). However, other substrates were also used (cobble, 21 of 130; silt/clay, 18 of 130; gravel, 16 of 130; and sand, 12 of 130). Length and age covariates were not associated with substrate selection. Selection of leaf pack habitat supports the importance of terrestrial organic material and riparian zones to yellow-phase American eels in riverine systems. 


\section{Acknowledgments}

I would like to thank Dr. Stuart Welsh, FirstEnergy Corp, the West Virginia Division of Natural Resources, and the West Virginia Cooperative Fish and Wildlife Research Unit for giving me this opportunity, letting me be a part of this research project, and to work with this amazing species. Also a special thank you to my advisor and committee chair Dr. Stuart Welsh, for his support, helpful suggestions, and contributions to my various learning experiences. I would like to extend a special thanks to Dr Patricia Mazik and Dr. David Smith for being on my graduate committee. And thank you to Dr. George Merovich and Dr. David Smith for their extensive time and effort in teaching me statistics and assisting me with the statistical process for this study.

A special thanks to Ken Oliveira, at University of Massachusetts, Dartmouth, for his time teaching me otolith aging techniques. Additionally, I would like to thank the Dr. Vicki Blazer Lab, at the Leetown Science Center, for histologically sexing the eels and allowing me to use their lab facilities.

A special thanks to my field and laboratory help including Ryan Braham, Nicole Dawson, Corbin Hilling, Ross Andrew, and Cat Artis. And a thank you to Becky Nestor for always being there when I needed her.

Finally, I would like to thank my family and friends for their support and encouragement throughout the past two years. Especially my family for encouraging my curiosity with the natural world. I would like to thank the love of my life, my husband Ryan, for his help in the field, in the lab, battling huge spiders, and for his emotional support, patience, and most of all his love. Without him none of this would have been possible. 


\section{Table of Contents}

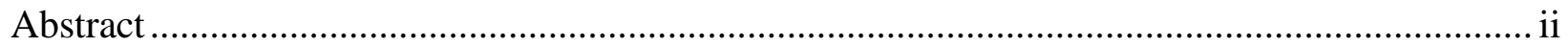

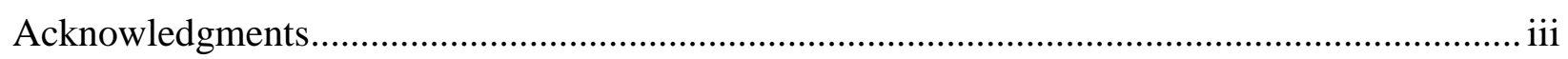

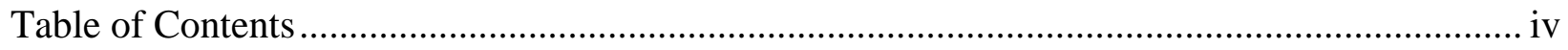

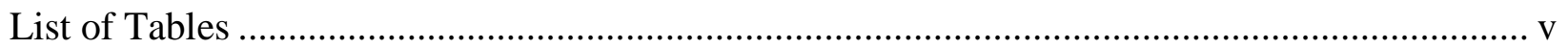

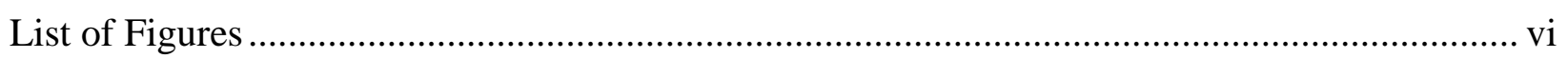

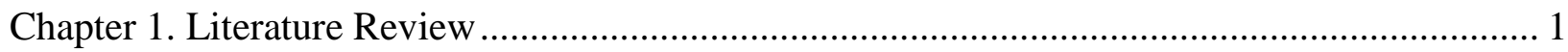

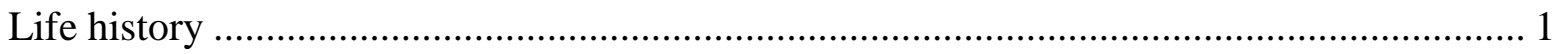

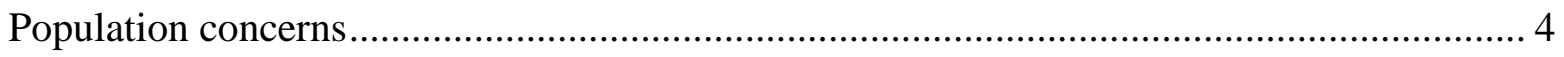

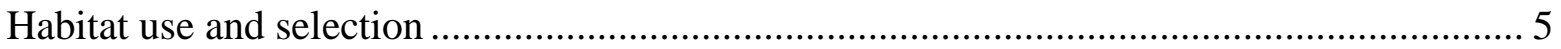

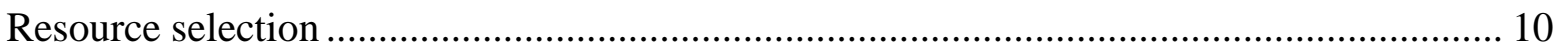

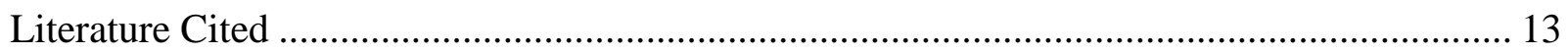

Chapter 2. An experimental study of benthic habitat selection in yellow-phase American eels

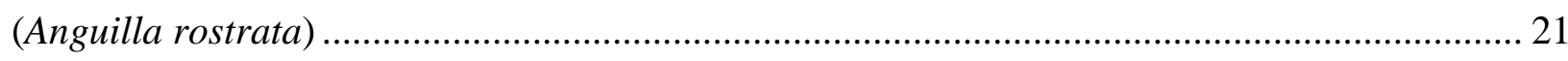

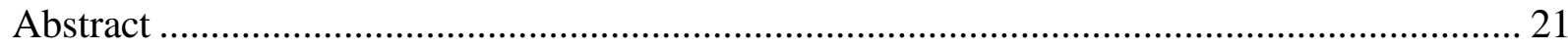

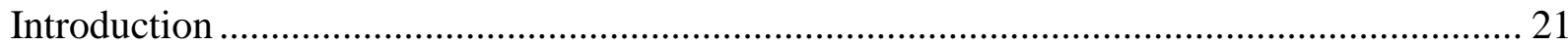

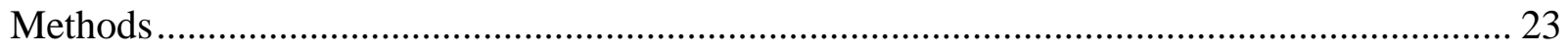

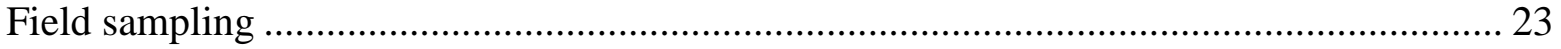

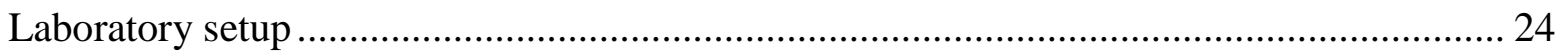

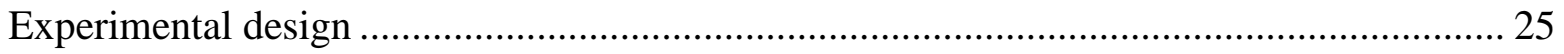

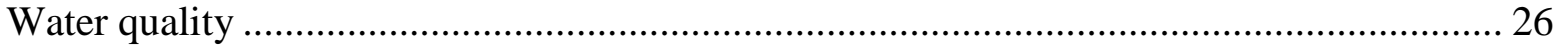

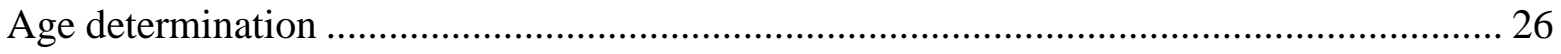

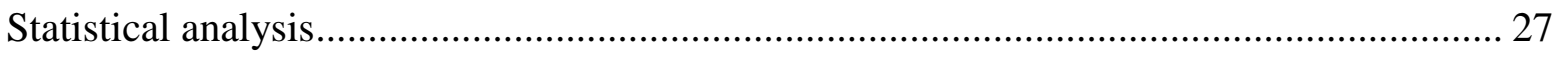

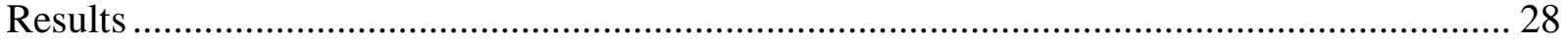

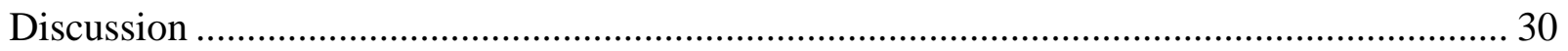

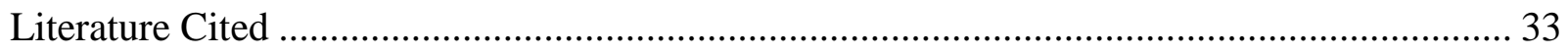

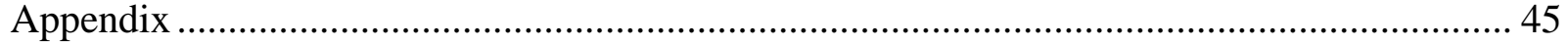




\section{List of Tables}

Table 1.1. Literature review of past anguillid microhabitat use research relating to substrate selection or preference.

Table 2.1. Deviance statistics from a multinomial logistic regression analysis assessing the influence of aquarium and trial categories on substrate selection by American eels.

Table 2.2. Total number and percentage of yellow-phase American eel selecting each substrate. Odds ratios, standard errors (SE), and $95 \%$ Confidence Intervals (CI) for eel substrate selection of leaf pack versus all others.

Table 2.3. Deviance statistics from a multinomial logistic regression analysis assessing the influence of age and total length covariates on substrate selection by American eels. 


\section{List of Figures}

Figure 2.1. Diagram of recirculation system design for the holding tank system (A) and the substrate experiment system (B).

Figure 2.2. Photograph A shows the aquarium setup with one substrate bin removed to show fish friendly foam in place. Photograph B is the aquarium setup with substrate bins and fish friendly foam. Note the leaf pack substrate bin is being held in place by two wooden dowels. 40

Figure 2.3. Length frequencies of 117 eels collected at the Millville Dam eel ladder and used during the substrate selection laboratory study. Lengths ranged from 224 to $338 \mathrm{~mm}$ (mean $=273$ $\mathrm{mm}$, standard error $=2.34$ ). Length categories are $10 \mathrm{~mm}$ intervals (e.g. the 230 length category represents eel lengths from 221 to $230 \mathrm{~mm}$ ).

Figure 2.4. Consensus age frequencies of 117 eels collected at the Millville Dam eel ladder and used during the substrate selection laboratory study. The consensus ages ranged from 3 to 11 years $($ mean $=6$ years, standard error $=0.157)$.

Figure 2.5. Box plot depicting the American eel use of five equally available substrate types as a function of total length $(\mathrm{mm})$. Bolded lines within the grey boxes are the median values, the grey boxes represent lower and upper quartile values, and the ends of the dotted lines represent maximum and minimal values. Lengths ranged from 224 to $338 \mathrm{~mm}(\mathrm{n}=117$, mean $=273 \mathrm{~mm}$, standard error $=2.34$ ).

Figure 2.6. Box plot depicting American eel use of five equally available substrate types as a function of age. Bold lines within grey boxes are median values, grey boxes represent lower and upper quartile values, ends of dotted lines represent maximum and minimal values, and open circles represent outliers. Consensus ages ranged from 3 to 11 years $(n=117$, mean $=6$ years, standard error $=0.16$ ) 


\section{Chapter 1. Literature Review}

This thesis focuses on benthic habitat use of yellow-phase American eels (Anguilla rostrata). The thesis is comprised of two chapters: (1) an introduction and literature review on the life history and habitat selection of the American eel, and (2) an experimental study on microhabitat preference of yellow-phase American eels and relationships between preference and age and length. For this study, I quantified substrate use of yellow-phase American eels in a controlled laboratory environment. An increased understanding of microhabitat use by American eels is warranted, because population decline of the American eel has been attributed, in part, to habitat alterations.

\section{Life history}

The American eel, a catadromous species with an extraordinary life history, spawns in the Sargasso Sea potentially in a panmictic fashion (Tesch 1977; Avise et al. 1986; Helfman et al. 1987). The Sargasso Sea is a part of a large clockwise gyre, located in the North Atlantic Ocean south of Bermuda (Tesch 1977; Fahay 1978; Facey and Van Den Avyle 1987). The American eel has an enormous geographical range stretching from the southern tip of Greenland through North America, Central America, and to Venezuela (Tesch 1977). American eels are referred to as being highly adaptive due to their enormous range and their ability to move from oceanic to freshwater habitats.

There are five primary life stages of the American eel: leptocephalus, glass, elver, yellow, and silver (Tesch 1977; Fahay 1978). Spawning occurs in the Sargasso Sea during the winter and early spring (Schmidt 1923). The actual spawning location has been hypothesized as an area in the southern warmer region of the Sargasso Sea, in the upper $500 \mathrm{~m}$ section of the water column 
(Kleckner et al. 1983; McCleave et al. 1987). The exact location of the spawning area and the specific spawning activities are still somewhat mysterious. Following the egg hatch, the eel begins a brief pre-larval stage which then enters into the translucent, laterally compressed leptocephalus stage. The leptocephali passively drift and actively swim in the upper $350 \mathrm{~m}$ of the ocean water column for several months while ocean currents carry them along the continental shelf where they are randomly dispersed (Kleckner and McCleave 1982, 1985; Avise et al. 1986). At this point, the American eel metamorphoses into a translucent serpentine-shaped glass eel. During winter and spring, glass eels migrate toward land and ascend estuaries while some may continue into river systems (ASMFC 2000; Dutil et al. 2009). Glass eels metamorphose into pigmented elvers (Fahay 1978). At this stage the eel uses soft, undisturbed bottom sediment as shelter during migration (Facey and Van Den Avyle 1987). Elvers may move up into freshwater or stay in coastal rivers and estuarine habitats (Facey and Van Den Avyle 1987). As the elvers grow larger $(>127 \mathrm{~mm})$ and show a pigment change from brown to yellow or green; they are then considered yellow-phase eels (Facey and Van Den Avyle 1987; ASMFC 2000).

The yellow-phase is the dominant growth phase and the longest life stage of the American eel (Tesch 1977; Facey and Van Den Avyle 1987; Oliveira 1999). American eel growth rates in both males and females are inversely correlated to latitude along the North American Atlantic Coast (Oliveira 1999; Oliveira and McCleave 2002; Jessop 2010). American eel diets include invertebrates, crustaceans, bivalves, polychaetes, and fishes. The diet of small yellow-phase eels, less than $400 \mathrm{~mm}$ total length (TL), consists of bottom dwelling invertebrate larvae commonly including Ephemeroptera, Megaloptera, and Trichoptera (Ogden 1970; Facey and LaBar 1981). Wenner and Musick (1975) found a positive correlation between eel size and the size of prey items. Larger eels, typically feed on crayfishes or fishes, and to a lesser extent, 
carrion (Ogden 1970; Facey and LaBar 1981). Eels are able to use three modes of feeding (suction, shaking, and spinning). Shaking and spinning (up to 14 rotations/sec) are feeding strategies which allow American eels to overcome gape-limitation (Helfman and Clark 1986).

In the Potomac River drainage of the Mid Atlantic region, many yellow-phase eels migrate upstream from spring through fall with little movement in winter (Hildebrand 2005; Hammond and Welsh 2009). Upstream migration is influenced by lunar cycle, water temperature, and river discharge (Lamothe et al. 2000; Hildebrand 2005; Hammond and Welsh 2009). Hildebrand (2005) compared daily eel collections with daily environmental conditions and found that new moon periods (low light levels), and increased river discharge were associated with upstream migration of yellow-phase eels in the lower Shenandoah River. In addition to upstream migration, yellow-phase eels often maintain home ranges with restricted short-range movements and high site fidelity (Gunning and Shoop 1962; Parker 1995; Oliveira 1997; Lamothe et al. 2000).

Sexually mature silver-phase eels begin the downstream spawning migration to the Sargasso Sea (Oliveira 1997, 1999). In some cases, large yellow-phase American eels may begin outmigration prior to metamorphosing to the silver phase. Yellow-phase American eels are initially sexually undifferentiated. Environmental factors may influence timing and resulting sexual differentiation prior to spawning migration (Facey and Van Den Avyle 1987; Krueger and Oliveira 1999; Oliveira 1999). High eel density can influence eels to develop into males while low density can influence eels to develop into females (Krueger and Oliveira 1999; Oliveira 1999). Oliveira (1999) suggested size as an important spawning migration trigger. Ages of spawning migrants varied, but length ranges were similar (Oliveira 1999). However, lengths of spawning migrants differ between sexes indicating that males may have a more limited size at 
migration (Helfman et al. 1987; Oliveira 1999; Oliveira and McCleave 2002). Females may have a size maximizing life history strategy and migrate at optimal body size to increase fecundity (Helfman et al. 1987; Oliveira 1999; Oliveira and McCleave 2002). There is evidence of latitudinal variation in age, size, and growth rate at maturity (Helfman et al. 1987; Oliveira 1999; Jessop 2010). Female size at maturation was positively correlated to latitude while age had no apparent relation (Helfman et al. 1987; Oliveira 1999; Jessop 2010). However, male age was positively related to latitude but size was not related (Helfman et al. 1987; Oliveira 1999; Jessop 2010). Spawning migration typically occurs in the fall but has been observed during other times

of the year (Euston et al. 1998; S. Eyler unpublished data). Kleckner et al. (1983) suggested that semelparous silver eels use water temperature cues to stop migration in the southern Sargasso Sea and begin spawning activities.

\section{Population concerns}

The focus on American eels has increased recently owing to economic worth (international food market and domestic bait fishery) and population decline (Castonguay et al. 1994; Haro et al. 2000; Casselman 2003). Historically, American eels likely comprised a large portion of the total biomass in some aquatic systems (Ogden 1970; Meffe and Sheldon 1988). Throughout its range, historic abundance data suggest that the eel population has been on the decline since 1970 to 1985 (ASMFC 2000; COSEWIC 2006). Regional declines, such as in the St. Lawrence River, have been used as indicators of whole population decline (Oliveira 1999; COSEWIC 2006). Unlike anadromous species that return to their natal streams, the larval eel recruitment class migrates to continental waters more or less at random with respect to the widespread geographical origins of the parental genes. Several factors may contribute to population decline of American eels, such as overharvesting, oceanic influences (North Atlantic 
oscillation, climate change), contaminants, barriers (reduced range, turbine mortality), and habitat loss (Castonguay et al. 1994; Haro et al. 2000; Casselman 2003).

Due to the population decline, the Committee on the Status of Endangered Wildlife in Canada (COSEWIC) designated the American eel as a species of Special Concern in April 2006. The COSEWIC designation was based, in part, on abundance declines of American eels beginning in the 1970s in the upper St. Lawrence River and Lake Ontario (COSEWIC 2006). The U.S. Fish and Wildlife Service and NOAA Fisheries completed a 12-month status review to examine the need for listing the American eel as threatened or endangered, through the Endangered Species Act (USFWS 2007). The status review did not support ESA listing, in part, because of the wide distribution and overall population abundances of the American eel (USFWS 2007). In 2010, the U.S. Fish and Wildlife Service received a second petition to list the American eel and again initiated a status review of the species (USFWS 2011). The 2010 had not made a determination prior to the completion of this thesis. In 2000, the Atlantic States Marine Fisheries Commission created a Fishery Management Plan for American eel to protect and conserve the resources in its ecosystem and for continued commercial, recreational, scientific, and educational use (ASMFC 2000). The plan calls for increased understanding of the factors that limit eel distribution, abundance, and productivity, including an increased understanding of American eel habitat requirements.

\section{Habitat use and selection}

American eels occur in a wide range of freshwater, marine, and brackish habitats, including streams, lakes, marshes, open oceans, and estuaries (Tesch 1977; Fahay 1978; Facey and Van Den Avyle 1987; Helfman et al. 1987). American eels often forage at night and burrow into or hide under benthic substrates for daytime concealment (Ogden 1970; Tesch 1977; Hedger 
et al. 2010). Habitats for daytime concealment may provide cover from predation, space for circulating water for oxygen exchange, and foraging opportunities. Yellow-phase eels often stay in dimly lit to dark locations. The retina of the yellow-phase eel contains close to 10 times the number of rods than that of most diurnal fishes; only fishes that live in extremely dark habitats have more rods (Tesch 1977). Eels may burrow into benthic substrate as a defense from lowering water levels or to reduce predation risk (Tesch 1977). Benthic substrates selected by eels could be influenced by interspecific and intraspecific competition, the availability of suitable habitat, chemical and physical tolerances, and dispersal abilities (Fretwell and Lucus 1970; Rosenzweig 1981; Leftwich et al. 1997). Although, there could be limited interspecific competition for daytime eel habitat due to few other freshwater fish exhibiting similar habitat use (Fahay 1978; Facey and Van Den Avyle 1987).

Habitat selection can be thought of as a hierarchy of selection with macrohabitat defined as the species geographical range or at the watershed level, mesohabitat being a home range, and microhabitat defined as a certain habitat components within the species' home range (Johnson 1980; Meffe and Sheldon 1988; Orians and Wittenberger 1991; Leftwich et al. 1997). It is also important to understand the hierarchical process of habitat selection, in that, the individual within the microhabitat has likely made a crucial selection by choosing the home range that includes the microhabitat (Johnson 1980; Jones 2001; Manly et al. 2002).

Anguillid eels use a wide range of macrohabitats; however few studies have found a consistent pattern of microhabitat use of benthic substrate (Table 1.). In addition, previous research on the use of riverine microhabitat by anguillids has mainly been observational. Tesch (1977) reported a wide range of habitats used by anguillids, including mud, sand, tube-like burrows, edges of weed beds, tree stumps, roots, and most anything else which provided suitable 
shelter. He also suggested that the body size of anguillids influences substrate use. For example, A. marmorata burrows in sand or under stones until it reaches a length of about $300 \mathrm{~mm}$ TL then it shifts to mud tubes (Tesch 1977). Meffe and Sheldon (1988) found large American eels in the Savanna River within muddy and leafy substrates in slow moving water. Small eels were found in muddy and sandy substrates in fast water. Although, these selections were conditional on that the Savanna River had limited amounts of gravel, and an absence of cobble and boulder substrates. In a salt marsh, Ford and Mercer (1986) observed large and small American eels in soft mud substrates but also observed large eels in sandy substrates. During electrofishing in the South Fork Shenandoah River, high catch rates of large eels, predominately 700-900 mm TL (range 292-1023 mm TL), were observed in leaf packs, root wads, and woody debris (Goodwin and Angermeier 2003).

Results of various American eel radio telemetry studies can be inconsistent regarding benthic substrate use. Telemetered yellow-phase American eels ( $\geq 500 \mathrm{~mm}$ TL) used habitat differently among sites and among seasons in three James River tributaries (South Fork Tye River, South Fork Piney Creek, Shoe Creek; Strickland 2002). In South Fork Piney Creek, eels used pool habitats in the spring and summer, occurred in the deepest locations in spring, but did not demonstrate a substrate selection during any of the seasons. No habitat units or depth selections were found during any of the seasons in the South Fork Tye River but a consistent selection for cobble occurred year-round. In Shoe Creek, pools were the selected habitat unit in all seasons, depth (31-125 mm) was only selected for in the fall, and varying dominant substrate selections (cobble, small gravel, and bedrock) through the fall, winter, and spring, respectively. Telemetered yellow-phase American eels, (500-685 mm TL) also displayed habitat use changes seasonally and diurnally in a Delaware impoundment (Thomas 2006). However in this study, 
American eels used very course substrates during winter and spring months, sand, silt, and clay during summer, and very fine substrates in fall. Further, eels used coarser substrates during morning and afternoon, and areas with sand, silt, and clay during evening and night.

Modeling studies of Smogor et al. (1995) and Wiley et al. (2004) did not find significant habitat associations of American eels in relation to substrate or other physical microhabitat parameters. Both Smogor et al. (1995) and Wiley et al. (2004) examined multiple physical, chemical, and biological habitat variables. At larger spatial scales, Smogor et al. (1995) found that densities of small- and medium-sized American eels decreased with distance from the ocean. Eel densities were not associated with local habitat features. However, a slight positive relationship was found between American eel density and total fish density, which was attributed to the relative productivity of the system. Wiley et al. (2004) reported relationships of American eel density with velocity-depth diversity (adjusted $\mathrm{R}^{2}=17.4 \%$ ), distances from Chesapeake Bay (adjusted $\mathrm{R}^{2}=12.3 \%$ ), and total fish density (adjusted $\mathrm{R}^{2}=7.7 \%$ ). Densities of American eels were positively correlated with increased velocity depth regimes, short distances from the Chesapeake Bay, and higher densities of non-eels fishes. Impeded movements of eels due to semi-passable and impassable barriers could have affected habitat relations (Smogor et al. 1995; Wiley et al. 2004).

Habitat use of a related anguillid species, the European eel (A. anguilla), is likely similar to that of the American eel. Some of the American eel life history knowledge has been inferred from data on other Anguillids including the European eel due to the species having many life history similarities (i.e. overlapping spawning area, diet, macrohabitat relations). Similar to American eel findings (Tesch 1977; Ford and Mercer 1986; Meffe and Sheldon 1988), Laffaille et al. (2003) suggested that European eels change behavior and microhabitat use at differing 
length classes. They found non-significant selection differences between the ecological profiles reviewed and the four size classes. The small European eels $(<300 \mathrm{~mm}$ TL) selected shallow $(<$ $6 \mathrm{~m}$ ) habitats, with flow velocities of greater than $0.1 \mathrm{~m} \cdot \mathrm{s}^{-1}$, substrates of gravel, pebble, and/or boulders, medium to high densities of aquatic vegetation, and low riparian vegetation cover. However, 300-450 mm TL eels, did not select for depth or substrates composed of sand, gravel, pebbles, and boulders. Eels greater than $450 \mathrm{~mm}$ TL had no avoidance of silt and high riparian vegetation cover and did not select for or against aquatic vegetation density (Laffaille et al. 2003). Similar to American eel findings, eel densities were influenced by the distance from sea, water depth, and river flow, and eel length classes increased with distance from the sea (Smogor et al. 1995; Laffaille et al. 2003; Wiley et al. 2004). While microhabitat variables (i.e. substrate, cover) explained less variance in models with total eel densities, data partitioned by length categories supported differences in some variables.

Research studies on anguillid species in Australia and New Zealand have examined habitat selection with different size classes. Field and laboratory studies have been conducted on habitat selection of the shortfinned eel (A. australis) and longfinned eel (A. dieffenbachii). Jellyman et al. (2003) hypothesized that there may be intraspecific and interspecific habitat selection variations for these two species. They sampled four stream types and collected data on twenty habitat variables during a study of habitat use in shortfinned (56-840 $\mathrm{mm} \mathrm{TL})$ and longfinned eels (66-1035 mm TL). Small shortfinned eels measuring less than $100 \mathrm{~mm}$ and measuring 200-299 mm had higher abundances in large substrates while larger shortfinned eels (> $400 \mathrm{~mm}$ ) had higher abundances in fine substrates. Small longfinned eels (100-199 mm) were found at higher abundances in large substrates while larger longfinned eels had no abundance association with substrate size but were associated with undercut banks, surface cover 
(overhanging, floating organic materials), aquatic plant cover, and debris cover. Larger shortfinned eels (> $500 \mathrm{~mm}$ ) also were associated with aquatic plant cover.

Glova (1999) completed shortfinned eel and longfinned eel cover preference tests using natural (macrophytes, woody debris, and cobble) and artificial (plastic pipes and shade) cover types in replicated channels. He compared the two species of juvenile eel and three length categories small (<100 mm TL), medium (100-199 mm TL), and large (200-299 mm TL). When tested separately, both species in the small and medium categories preferred cobble and macrophytes equally while large eels of both species strongly preferred macrophytes and to a lesser extent cobbles. When the eel species were placed in the channels together, longfinned eels preferred cobble while the shortfinned eels preferred macrophytes and woody debris.

In a laboratory experiment, Silberschneider et al. (2004) examined estuarine cover preferences of glass-phase shortfinned and the introduced longfinned (A. reinhardtii) eels. Approximately 24 to 30 eels of each species were released into separate experimental tanks containing sand, sea grass, rock/cobble, and mud. Shortfinned eels preferred heterogeneous habitats or rocks/cobble over the homogeneous habitats. Longfinned eels preferred combinations of rocks/cobble over sand, mud, and sea grass.

\section{Resource selection}

Resource selection is thought of as a hierarchical decision making process of complex behavioral and environmental responses (Fretwell and Lucus 1970; Rosenzweig 1981; Krausman 1999; Jones 2001; Manly et al. 2002). Rosenzweig (1981) described differential habitat selection as one of the principal relationships which permit species to coexist. It is thought that a species would select a particular resource that it considers high quality over a lower quality resource 
(Fretwell and Lucus 1970; Rosenzweig 1981; Manly et al. 2002). This selected higher quality resource would increase the species success in growth, fitness, and ultimately its survival (Morrison et al. 1992; Krausman 1999; Manly et al. 2002; Railsback et al. 2003). However, Orians and Wittenberger (1991) pointed out that correlations between habitat features and success may be low or difficult to assess in the natural world. A normally good habitat may actually be unsuitable due to unforeseen factors, such as diseases, predator abundance, and decreased food supplies. Several factors are believed to contribute to resource selection including intraspecific and interspecific competition, natural selection, chemical composition or texture of resource, phylogenetic effects, predation risk, habitat patch size, and inter-patch distances (Fretwell and Lucus 1970; Rosenzweig 1981; Morrison et al. 1992; Leftwich et al. 1997; Manly et al. 2002).

Generally, wildlife and fisheries researchers have studied resource selection by comparing usage of resources (food or habitat) to the availability of the resource. Resource selection may be detected and measured by comparing any two of the used, unused, and available possible sets of resource units (Manly et al. 2002). In nature, the availability of resources can vary temporally and spatially, therefore use should be compared to availability (or unused) to be able to make valid conclusions concerning resource selection. Although an unused resource is sometimes difficult to distinguish from used, due to the fact that absence from the particular habitat does not imply that the habitat is being avoided (Garshelis 2000; Jones 2001). Johnson (1980) defined usage as the use of a quantity of a habitat component by the animal in a fixed period of time. And defined availability as the habitat components accessible to the animal (Johnson 1980). Although preference and selection have been used as synonyms (Thomas and Taylor 1990; Manly et al. 2002), Johnson (1980) defined preference as "a reflection of the 
likelihood of that component being chosen if offered on an equal basis with others" (use with equally available resources). And Selection as "a process in which an animal actually chooses that component" (use disproportionate to resource availability; Johnson 1980).

Resource selection studies have been scrutinized when they are used for modeling or projecting responses to habitat change (Railsback et al. 2003, Manly et al. 2002). Particularly, some have questioned the assumptions of a positive correlation between species density and habitat quality (Van Horne 1983; Garshelis 2000; Railsback et al. 2003) and the likelihood that an animal will use a habitat type if more of that type is available (Garshelis 2000; Railsback et al. 2003). Railsback et al. (2003) recommends understanding that resource selection studies should be in conjunction with studies of how key fitness factors (i.e. growth, survival success) depend on habitat characteristics. Prior to resource selection studies, researchers should consider the biology of the study species, and the spatial or temporal scales associated with the habitat units of the study (Orians and Wittenberger 1991). Researchers should also consider covariates that could affect habitat selection (e.g. sex, age, season, behavioral activities, and daily activities; Morrison et al. 1992; Jones 2001; Manly et al. 2002).

To improve conclusions made of resource selection studies several assumptions have been recommended (Manly et al. 2002): (1) the amount of available habitat does not change over the study period, (2) available resources are correctly identified, (3) resources are correctly identified as used or unused, (4) variables that could influence the probability of selection are correctly identified, (5) animals have free and equal access to all available resource types, (6) sampling locations are sampled randomly and independently, and (7) surveyed animals have equal detectability. 
The following chapter includes a laboratory study of benthic substrate selection by yellow-phase American eels. The study also examines the influences of American eel age and length on substrate selection. The results of these investigations are conditionally based on five substrate types; cobble (90-256 mm), gravel (4-16 mm), sand $(0.125-1 \mathrm{~mm})$, silt/clay $(<0.0625$ $\mathrm{mm}$ ), and leaf pack. These substrate types are common to many riverine habitats within the North American range of the American eel.

\section{Literature Cited}

ASMFC (Atlantic States Marine Fisheries Commission). 2000. Interstate fishery management plan for American eel (Anguilla rostrata). ASMFC, Fishery Management Report 36, Washington, D.C.

Avise, J. C., G. S. Helfman, N. C. Saunders, and L. S. Hales. 1986. Mitochondrial DNA differentiation in North Atlantic eels: population genetic consequences of an unusual life history pattern. Proceedings of the National Academy of Sciences of the United States of America, 83:4350-4354.

Casselman, J. M. 2003. Dynamics of resources of the American eel, Anguilla rostrata: declining abundance in the 1990s. Pages 255-274 in K. Aida, K. Tsukamoto, and K. Yamauchi, editors. Eel Biology. Springer-Verlag Tokyo.

Castonguay, M., P. V. Hudson, C. M. Couillard, M. J. Eckersley, J. D. Dutil, and G. Verreault. 1994. Why is recruitment of the American eel, Anguilla rostrata, declining in the St. Lawrence River and Gulf? Canadian Journal of Fisheries and Aquatic Sciences 51:479_ 488.

COSEWIC (Committee on the Status of Endangered Wildlife in Canada). 2006. COSEWIC assessment and status report on the American eel Anguilla rostrata in Canada. Committee on the Status of Endangered Wildlife in Canada. Ottawa. $\mathrm{x}+71 \mathrm{pp}$. 
Dutil, J. D., P. Dumont, D. K. Cairns, P. S. Galbraith, G. Verreault, M. Castonguay, and S. Proulx. 2009. Anguilla rostrata glass eel migration and recruitment in the estuary and Gulf of St Lawrence. Journal of Fish Biology 74:1970-1984.

Euston, T. E., D. D. Royer, and C. L. Simons. 1998. American eels and hydro plants: clues to eel passage. Hydro Review 94-103.

Facey, D. E. and G. W. LaBar. 1981. Biology of American eels in Lake Champlain, Vermont. Transactions of the American Fisheries Society 110:396-402.

Facey, D. E. and M. J. Van Den Avyle. 1987. Species profiles: life histories and environmental requirements of coastal fishes and invertebrates (north Atlantic): American eel. U.S. Fish and Wildlife Service Biological Report 82(11.74). U.S. Army Corps o f Engineers, TR EL-82-4.

Fahay, M. P. 1978. Biological and Fisheries Data on American eel, Anguilla rostrata (LeSueur). Technical Series Report No. 17. National Marine Fisheries Service, NOAA, Highlands, New Jersey.

Ford, T. E. and E. Mercer. 1986. Density, size distribution, and home range of American eels, Anguilla rostrata, in a Massachusetts salt marsh. Environmental Biology of Fishes 17:309-314.

Fretwell, S. D. and H. L. Lucas, Jr. 1970. On territorial behavior and other factors influencing habitat distribution in birds. I. Theoretical development. Acta Biotheoretica 19:16-36.

Garshelis, D. L. 2000. Delusions in habitat evaluation: measuring use, selection, and importance. Pages 111-164 in L. Boitani and T. K. Fuller, editors. Research Techniques in Animal Ecology, Controversies, and Consequences. Columbia University Press, New York.

Glova, G. J. 1999. Cover preference tests of juvenile shortfinned eels (Anguilla australis) and longfinned eels (A. dieffenbachii) in replicate channels. New Zealand Journal of Marine and Freshwater Research 33:193-204. 
Goodwin, K. R. and P. L. Angermeier. 2003. Demographic characteristics of American eel in the Potomac River drainage, Virginia. Transactions of the American Fisheries Society 132:524-535.

Gunning, G. E. and C. R. Shoop. 1962. Restricted movements of the American eel, Anguilla rostrata LeSueur, in freshwater streams, with comments on growth rate. Tulane Studies in Zoology 9:265-272.

Hammond, S. D. and S. A. Welsh. 2009. Seasonal movements of large yellow-phase American eels downstream of a hydroelectric dam, Shenandoah River, West Virginia. Pages 309323 in J. M. Casselman and D. K. Cairns, editors. Eels at the Edge: Science, Status, and Conservation Concerns. American Fisheries Society, Symposium 58, Bethesda, Maryland.

Haro, A. J., W. Richkus, K. Whalen, A. Hoar, W. D. Busch, S. Lary, T. Brush, and D. Dixon. 2000. Population decline of the American eel: implications for research and management. Fisheries 25(9):7-16.

Hedger, R. D., J. J. Dodson, D. Hatin, F. Caron and D. Fournier. 2010. River and estuary movements of yellow-stage American eels Anguilla rostrata, using a hydrophone array. Journal of Fish Biology 76:1294-1311

Helfman, G. S. and J. L. Clark. 1986. Rotational feeding: overcoming gape-limited foraging in anguillid eels. Copeia 1986:679-685.

Helfman, G. S., D. E. Facey, L. S. Hales, and E. L. Bozeman. 1987. Reproductive ecology of the American eel. American Fisheries Society Symposium. 1:42-56.

Hildebrand, H. 2005. Size, age composition, and upstream migration of American eels at the Millville Dam eel ladder, Shenandoah River, West Virginia. Master's thesis, West Virginia University, Morgantown.

Jellyman, D. J., M. L. Bonnett, and J. R. E. Sykes. 2003. Contrasting use of daytime habitat by two species of freshwater eel Anguilla ssp. in New Zealand Rivers. Pages 63-78 in D. A. 
Dixon, editor. Biology, Management, and Protection of Catadromous Eels. American Fisheries Society, Symposium 33, Bethesda, Maryland.

Jessop, B. M. 2010. Geographic effects on American eel (Anguilla rostrata) life history characteristics and strategies. Canadian Journal of Fisheries and Aquatic Sciences 67:326-346.

Johnson, D. H. 1980. The comparison of usage and availability measurements for evaluating resource preference. Ecology 61:65-71.

Jones, J. 2001. Habitat selection studies in avian ecology: a critical review. The Auk 118(2):557562.

Kleckner, R. C. and J. D. McCleave. 1982. Entry of migrating American eel leptocephali into the Gulf Stream system. Helgolander Meeresuntersuchungen 35:329-339.

Kleckner, R.C. and J. D. McCleave. 1985. Spatial and temporal distribution of American eel larvae in relation to North Atlantic Ocean current systems. Dana 4:67-92.

Kleckner, R. C., J. D. McCleave, and G. S. Wippelhauser. 1983. Spawning of American eel, Anguilla rostrata, relative to thermal fronts in the Sargasso Sea. Environmental Biology of Fishes 9:289-293.

Krausman, P. R. 1999. Some basic principles of habitat use. Pages 85-90 in K. L. Launchbaugh, K. D. Sander, and J. C. Mosley, editors. Grazing Behavior of Livestock and Wildlife. Idaho Forest, Wildlife and Range Experimental Station Bulletin 70, University of Idaho, Moscow.

Krueger, W. H. and K. Oliveira. 1999. Evidence for environmental sex determination in the American eel, Anguilla rostrata. Environmental Biology of Fishes 55:38-389.

Laffaille, P., E. Feunteun, A. Baisez, T. Robinet, A. Acou, A. Legault, and S. Lek. 2003. Spatial organisation of European eel Anguilla anguilla in a small catchment. Ecology of Freshwater Fish 12:254-264. 
Lamothe, P. J., M. Gallagher, D. P. Chivers, and J. R. Moring. 2000. Homing and movement of yellow-phase American eels in freshwater ponds. Environmental Biology of Fishes 58:393-399.

Leftwich, K. N., P. L. Angermeier, and C. A. Dolloff. 1997. Factors influencing behavior and transferability of habitat models for a benthic stream fish. Transactions of the American Fisheries Society 126:725-734.

Manly, B. F. J., L. L. McDonald, D. L. Thomas, T. L. McDonald, and E. P. Erickson. 2002. Resource Selection by Animals: Statistical Design and Analysis of Field Studies. Second edition. Kluwer Academic Publishers, Dordrechut, Netherlands.

McCleave, J. D., R. C. Kleckner, and M. Castonguay. 1987. Reproductive sympatry of American and European eel and implications for migration and taxonomy. American Fisheries Society Symposium 1:268-297.

Meffe, G. K. and A. L. Sheldon. 1988. The influence of habitat structure on fish assemblage composition in southeastern blackwater streams. The American Midland Naturalist 120:225-240.

Morrison, M. L., B. G. Marcot, and R. W. Mannan. 1992. Wildlife-Habitat Relationships: Concepts and Applications. University of Wisconsin Press, Madison, WI.

Ogden, J. C. 1970. Relative abundance, food habits, and age of the American eel, Anguilla rostrata LeSueur in certain New Jersey streams. Transactions of the American Fisheries Society 99:54-59.

Oliveira, K. 1997. Movements and growth rates of yellow-phase American eels in the Annaquatucket River, Rhode Island. Transactions of the American Fisheries Society 126:638-646.

Oliveira, K. 1999. Life history characteristics and strategies of the American eel, Anguilla rostrata. Canadian Journal of Fisheries and Aquatic Sciences 56:795-802.

Oliveira, K. and J. D. McCleave. 2002. Sexually different growth histories of the American eel in four rivers of Maine. Transactions of the American Fisheries Society 131:203-211. 
Orians, G. H. and J. F. Wittenberger. 1991. Spatial and temporal scales in habitat selection. The American Naturalist 137:S29-S49.

Parker, S. J. 1995. Homing ability and home range of yellow-phase American eels in a tidally dominated estuary. Journal of the Marine Biological Association of the United Kingdom 75:127-140.

Railsback, S. F., H. B. Stauffer, and B. C. Harvey. 2003. What can habitat preference models tell us? Tests using a virtual trout population. Ecological Applications 13(6):1580-1594.

Rosenzweig, M. L. 1981. A theory of habitat selection. Ecology 62:327-335.

Schmidt, J. 1923. The breeding places of the eel. Philosophical Transactions of the Royal Society of London Series B 211:179-208.

Silberschneider, V., B. C. Pease, and D. J. Booth. 2004. Estuarine habitat preferences of Anguilla australis and A. reinhardtii glass eels as inferred from laboratory experiments. Environmental Biology of Fishes 71:395-402.

Smogor, R. A., P. L. Angermeier, and C. K. Gaylord. 1995. Distribution and abundance of American eels in Virginia streams: tests of null models across spatial scales. Transactions of the American Fisheries Society 124:789-803.

Strickland, P. A. 2002. American eel distribution and growth in selected tributaries of the James River. Master's thesis. Virginia Polytechnic Institute and State University, Blacksburg.

Tesch, F. W. 1977. The Eel. Biology and Management of Anguillid Eels. Chapman and Hall, London.

Thomas, D. L. and E. J. Taylor. 1990. Study designs and tests for comparing resource use and availability Journal of Wildlife Management 54:322-330.

Thomas, J. 2006. American eel behavioral patterns in Silver Lake, Dover, Delaware. Master's thesis. Delaware State University, Dover. 
USFWS (U.S. Fish and Wildlife service). 2007. Endangered and threatened wildlife and plants; 12-month finding on a petition to list the American eel as threatened or endangered, Proposed Rules (50 CFR Part 17), Federal Register 72:22(2 February 2007):4967-4997.

USFWS (U.S. Fish and Wildlife service). 2011. Endangered and threatened wildlife and plants; 90-day finding on a petition to list the American eel as threatened, Proposed Rules (50 CFR Part 17), Federal Register 76:189(29 September 2011):60431-60444.

Van Horne, B. 1983. Density as a misleading indicator of habitat quality. Journal of Wildlife Management 47:893-901.

Wenner, C. A. and J.A. Musick. 1975. Food Habits and Seasonal Abundance of the American eel, Anguilla rostrata, from the Lower Chesapeake Bay. Chesapeake Science 16(1):6266.

Wiley, D., R. P. Morgan, and R. H. Hilderbrand. 2004. Relations between physical habitat and American eel abundance in five river basins in Maryland. Transactions of the American Fisheries Society 133:515-526. 
Table 1.1. Literature review of past anguillid microhabitat use research relating to substrate selection or preference.

\begin{tabular}{|c|c|c|c|c|}
\hline Author & Year & Species & Results of Substrate Selection/Preference Studies & Study \\
\hline Tesch & 1977 & Anguillids & Mud, sand, rock, and organic materials & Field observation \\
\hline Fahay & 1978 & A. rostrata & Mud and gravel & Field observation \\
\hline Ford and Mercer & 1986 & A. rostrata (large) & Soft mud to sandy & Field observation \\
\hline Ford and Mercer & 1986 & A. rostrata (small) & Soft substrates & Field observation \\
\hline Meffe and Sheldon & 1988 & A. rostrata (large) & Muddy and leafy & Field Study \\
\hline Meffe and Sheldon & 1988 & A. rostrata (small) & Muddy and sandy & Field Study \\
\hline Smogor et al. & 1995 & A. rostrata & No significant substrate selection & Field Study \\
\hline Glova $^{\mathrm{A}}$ & 1999 & A. australis $(200-299 \mathrm{~mm})$ & Macrophytes and minor preference for cobble & Laboratory study \\
\hline Glova $^{\mathrm{A}}$ & 1999 & A. australis $(<199 \mathrm{~mm})$ & Macrophytes and cobble & Laboratory study \\
\hline Glova $^{\mathrm{A}}$ & 1999 & A. dieffenbachii (200- $299 \mathrm{~mm})$ & Macrophytes and minor preference for cobble & Laboratory study \\
\hline Glova $^{\mathrm{A}}$ & 1999 & A. dieffenbachii $(<199 \mathrm{~mm})$ & Macrophytes and cobble & Laboratory study \\
\hline Strickland $^{\mathrm{B}}$ & 2002 & A. rostrata $(\geq 500 \mathrm{~mm})$ & Cobble & Field study \\
\hline Laffaille et al. & 2003 & A. anguilla $(>450 \mathrm{~mm})$ & No avoidance of silt and high riparian density & Field study \\
\hline Laffaille et al. & 2003 & A. anguilla $(300-450 \mathrm{~mm})$ & No substrate selection & Field study \\
\hline Laffaille et al. & 2003 & A. anguilla $(<300 \mathrm{~mm})$ & Gravel, pebble, boulders, and varied riparian/aquatic vegetation densities & Field study \\
\hline Jellyman et al. & 2003 & A. australis $(\geq 400 \mathrm{~mm})$ & Fine substrates & Field study \\
\hline Jellyman et al. & 2003 & A. australis $(<100 \mathrm{~mm})$ & Large substrates & Field study \\
\hline Jellyman et al. & 2003 & A. australis $(200-299 \mathrm{~mm})$ & Large substrates & Field study \\
\hline Jellyman et al. & 2003 & A. dieffenbachii (100-199 mm) & Large substrates & Field study \\
\hline Jellyman et al. & 2003 & A. dieffenbachii $(\geq 300 \mathrm{~mm})$ & Undercut banks, and surface, plant, and debris cover types & Field study \\
\hline Goodwin and Angermeier & 2003 & A. rostrata $($ median $=767 \mathrm{~mm})$ & Leaf packs, root wads, and woody debris & Field observation \\
\hline Silberschneider et al. ${ }^{\mathrm{C}}$ & 2004 & A. australis (glass eels) & Rocks/cobbles & Laboratory study \\
\hline Silberschneider et al. ${ }^{\mathrm{C}}$ & 2004 & A. reinhardtii (glass eels) & Rocks/cobbles & Laboratory study \\
\hline Wiley et al. & 2004 & A. rostrata & No significant substrate selection & Field Study \\
\hline Thomas & 2006 & A. rostrata $(500-685 \mathrm{~mm})$ & Seasonal differences between coarse, sand, silt, clay & Field Study \\
\hline
\end{tabular}




\title{
Chapter 2. An experimental study of benthic habitat selection in yellow-phase American eels (Anguilla rostrata)
}

\begin{abstract}
Given widespread habitat alteration of North American rivers, an understanding of the use and selection of habitat is important to conservation and management of the American eel. Yellow-phase American eels are often considered as habitat generalists, in part, because of their occurrence across a wide range of habitat types, but few experimental studies have examined microhabitat selection. In a laboratory experiment, I quantified microhabitat use of small yellowphase American eels $(n=130,224-338 \mathrm{~mm}$ TL) conditional on five benthic substrate types common to many rivers within the geographic range of the American eel. During nine, 4-day trials replicated with three aquaria, American eels were given a choice to burrow into five equally available benthic substrates: cobble (90-256 mm), gravel (4-16 mm), sand (0.125-1 $\mathrm{mm})$, silt/clay $(<0.0625 \mathrm{~mm})$, and leaf pack. Five American eels were used per aquaria for each trial, and individuals were used one time only. All eels were injected with PIT tags prior to the study, which allowed for determination of lengths and otolith-based ages of each individual following each trial. Leaf pack was selected with a significantly higher probability than other substrates (63 of 130 individuals). However, other substrates were also used (cobble, 21 of 130; silt/clay, 18 of 130; gravel, 16 of 130; and sand, 12 of 130). Length and age covariates were not associated with substrate selection. Selection of leaf pack habitat supports the importance of terrestrial organic material and riparian zones to yellow-phase American eels in riverine systems.
\end{abstract}

\section{Introduction}

American eels (Anguilla rostrata) have an extraordinary life history as a catadromous species that spawns in the Sargasso Sea (Tesch 1977; Avise et al. 1986; Helfman et al. 1987). The American eel has an enormous geographical range stretching from the southern tip of Greenland through North America, Central America, and to Venezuela (Tesch 1977). There are five primary life stages of the American eel: leptocephalus, glass, elver, yellow, and silver (Tesch 1977; Fahay 1978). Although all phases are important, the yellow-phase, the dominant growth phase, is the longest life stage of the American eel (Tesch 1977; Facey and Van Den Avyle 1987; Oliveira 1999). Throughout its life stages the species occurs in a wide range of habitats, such as marine and brackish waters, streams and rivers, and lakes and ponds (Tesch 
1977; Fahay 1978; Facey and Van Den Avyle 1987; Helfman et al. 1987). American eels are nocturnal, often foraging at night and burrowing during the daytime for cover (Tesch 1977; Fahay 1978; Ford and Mercer 1986; Facey and Van Den Avyle 1987; Meffe and Sheldon 1988; Strickland 2002; Goodwin and Angermeier 2003; Hedger et al. 2010).

The focus on American eels has increased recently owing to economic worth (international food market and domestic bait fishery) and population decline (Castonguay et al. 1994; Haro et al. 2000; Casselman 2003). Castonguay et al. (1994) and Haro et al. (2000) described many of the potential causes for population decline (i.e. overharvesting, oceanic influences, and habitat alteration). Although habitat alteration may contribute to population decline, there is little information available on habitat use of American eels (ASMFC 2000). Specifically, habitat studies on American eels have found a wide range of macrohabitat use; however, few studies have examined microhabitat. Meffe and Sheldon (1988) found large American eels in muddy leafy substrates and small eels in muddy, sandy substrates. In addition, Goodwin and Angermeier (2003) had higher catch rates of large American eels in leaf pack and other organic materials. In contrast, Ford and Mercer (1986) observed large and small American eels in soft mud bottomed substrates but also observed large eels in sandy substrates. Large ( $\geq$ $500 \mathrm{~mm}$ TL) American eels in a James River tributary consistently selected cobble; however, substrate use differed among tributaries and among seasons (Strickland 2002). Modeling studies of Smogor et al. (1995) and Wiley et al. (2004) did not find significant habitat associations of American eels in relation to substrate or other microhabitat variables.

Resource selection studies on other anguillid species may be useful for comparison with American eels given similarities among anguillid species. European eels (A. anguilla), with all size classes combined, showed no significant avoidance or selection for microhabitat; however after partitioning the size classes out, Laffaille et al. (2003) was only able to show non- 
significant to slight differences in microhabitat selections. Two Pacific Ocean eel species, shortfinned (A. australis) and longfinned eel (A. dieffenbachii), displayed size-related differences in habitat associations (Jellyman et al. 2003). Glova (1999) found differential resource selections of longfinned and shortfinned eels depending on length categories or interspecific competition. In a laboratory experiment, shortfinned and introduced longfinned (A. reinhardtii) glass eels selected heterogeneous combinations of rocks and cobble over sand, mud, and sea grass (Silberschneider et al. 2004).

Laboratory experiments, similar to those conducted by Glova (1999) and Silberschneider et al. (2004), have not been published on substrate selections of yellow-phase American eels. The objective of this study was to determine yellow-phase American eel microhabitat selection for or against five benthic substrate types. I also examined the relationship of length and age with microhabitat selection. Although results are conditionally-based on five benthic habitat types, information from this laboratory study may be applicable to our understanding of yellow-phase American eel selection of riverine microhabitats, given that the experimental benthic substrates are common to many Atlantic Coast drainages.

\section{Methods}

\section{Field sampling}

Yellow-phase American eels were collected during July 2011 from an eel ladder at the Millville hydroelectric dam, Shenandoah River, West Virginia. The Millville hydroelectric dam (owned and operated by FirstEnergy) is located approximately $9 \mathrm{~km}$ upstream from the confluence of the Potomac and Shenandoah rivers, $100 \mathrm{~km}$ upstream of the Potomac River at head of tide, and $285 \mathrm{~km}$ upstream from the mouth of the Potomac River estuary. A total of 150 
individuals (224-338 mm TL) were transported to the laboratory in coolers with aerated stream water.

\section{Laboratory setup}

Within the laboratory, the 150 American eels were subdivided into four holding tanks and acclimated to the laboratory setting prior to the substrate experiment. Each holding tank system encompassed two 378.5 L plastic tanks and one 378.5 L plastic sump (Figure 2.1a). Approximately two weeks before the experiment, eels were anesthetized with Tricaine methanesulfonate (MS-222) and tagged anterodorsolaterally with passive integrated transponder tags (PIT) and measured to the nearest mm TL (Zimmerman and Welsh 2008). The PIT tags provided identification for each individual, and allowed for analysis of relationships among length, age, and microhabitat selection.

The experimental system encompassed three glass aquaria $(473.2 \mathrm{~L})$ and one $378.5 \mathrm{~L}$ plastic sump (Figure 2.1b). Both the holding and the experimental systems used recirculation systems where reverse osmosis filtered water was gravity fed from aquaria to the sump and pumped, using a 1/8 horsepower sequence pump, back into the tanks. The water level in each aquarium was approximately $33 \mathrm{~cm}$ (23 cm below the top) which prevented eels from escaping. Each aquarium had five equally available substrates in separate removable, $39.4 \mathrm{~cm}$ long by 29.2 $\mathrm{cm}$ wide by $21.1 \mathrm{~cm}$ deep, plastic bins. Spaces in between the plastic bins were fitted with foam, preventing eel use of those areas (Figure 2.2a; New England Foam, Hartford, Connecticut).

Five substrates were examined during this experiment: cobble $(90-256 \mathrm{~mm}$, measured across the longitudinal axis), gravel $(4-16 \mathrm{~mm})$, sand $(0.125-1 \mathrm{~mm})$, silt/clay $(<0.0625 \mathrm{~mm})$, and leaf pack. These five substrate types were chosen based on their commonality to American eel habitat in many North American rivers, and because of their use in other American eel habitat studies (Tesch 1977; Ford and Mercer 1986; Meffe and Sheldon 1988; Strickland 2002; 
Goodwin and Angermeier 2003; Thomas 2006). The cobble, gravel, sand, and silt/clay

classifications were based on a modified Wentworth grain scale (Wentworth 1922). The gravel, sand, and silt/clay substrates were dried in an oven and separated using U.S. and metric standard testing sieves and a vibratory sieve shaker (Retsch GmbH., Haan, Germany). The leaf pack substrate was rinsed with filtered water and dried to remove mud and potential invertebrates. The leaf pack consisted mainly of maple (Acer spp.), sycamore (Platanus occidentalis), tulip poplar (Liriodendron tulipifera), oak (Quercus spp.), American beech (Fagus grandifolia) and birch (Betula spp.) leaves. To keep the leaf pack substrate inside the plastic bin, I used a loose mesh of $2 \mathrm{lb}$ test fishing line which allowed entrance and exit of eels within the leaf pack. A wooden dowel was wedged between the top lip of the plastic bin and the top lip of the aquarium to keep the leaf pack bin from floating (Figure 2.2b).

\section{Experimental design}

The substrate use experiment consisted of 9 trials during which five randomly chosen eels from holding tanks were released into each of the three aquaria. On the fourth day of the trial, the substrate bins were fitted with plastic lids, removed from aquaria, and inspected for the presence of eels. After recording counts of eel presence and PIT tag numbers, the post-trial eels were prepared for age determination (see methods below) and new individuals were released into the aquaria until all subsequent trials were completed.

Eels are known to have a strong sense of smell (Tesch 1977; Facey and Van Den Avyle 1987); therefore, precautions were taken to reduce an influence of eel scents in substrates among trials. Two sets of substrates with plastic bins were used during the experiment. In between the trials, substrates from the prior trial were placed in areas to dry while the second set of substrate bins were randomly placed back in the aquarium for the next trial. During this time I revaluated the amount of substrate in each bin and added more to maintain equal substrate amounts 
throughout the study period. Substrates were kept at an approximate level of $7.6 \mathrm{~cm}$ from the top of the plastic bins, which reduced substrate losses during eel burrowing.

\section{Water quality}

In holding and experimental tanks, water quality was monitored daily for conductivity, total ammonia nitrogen, temperature, dissolved oxygen, unionized ammonia, nitrite, hardness, alkalinity, and visual inspections of turbidity/algae (WVU-ACUC 2011). If water quality measurements exceeded designated WVU-ACUC ranges, then I exchanged $50 \%$ of the water. To maintain water quality, I used a charcoal filter in the inflow to the sump, ammonia was controlled by ammonia towers (bio balls) in the sump along with sponge-filter aeration, and an ultra violet light was used to sterilize water. Aquarium water temperatures fluctuated between $14-18^{\circ} \mathrm{C}$. The photoperiod was $12 \mathrm{hrs}$ of light and $12 \mathrm{hrs}$ of dark throughout the experiment. Eels were fed frozen enriched bloodworms (Hikari, Hayward, California; San Francisco Bay Brand Inc, Newark, California) and brine shrimp (San Francisco Bay Brand Inc, Newark, California) daily. Food was evenly distributed in the aquaria in an effort to not influence substrate bin selection.

\section{Age determination}

Ages of American eels were determined by counting annual rings of the sagittal otolith. Eel otoliths are known to contain complete and incomplete false annuli, (Liew 1974; Oliveira 1996; Morrison and Secor 2003), and bias from false annuli were reduced by following aging techniques of Oliveira (1996). Sagittal otoliths were exposed by a lateral cut through the top of the head cavity. The pair of otoliths were then removed, cleaned of extraneous tissue, and stored in a labeled coin envelope for subsequent processing and analysis. One of each pair of otoliths was embedded in epoxy resin for $48 \mathrm{hrs}$ or until hardened. The otoliths were transversely sectioned to an approximate $0.18 \mathrm{~mm}$ thickness using an Isomet low speed saw (Buehler Inc. 
Lake Bluff, Illinois). Sections were then etched for three to five minutes with $5 \%$

ethylenediaminetetraacetic acid (EDTA) with a pH of 6 and stained for two to three minutes with $0.01 \%$ toluidine blue (Oliveira 1996). The stain treatment enhanced the accuracy of age estimation, in part because transmitted light through blue opaque (summer) zones aided in the differentiating of false annuli. Sections were then read, by two independent readers, under transmitted light with a stereoscope using $100 \mathrm{x}$ magnification. The two readers assessed the readability of each otolith using the following grades; $(0=$ unreadable, $1=$ low readability, $2=$ mid readability, and 3 = high readability). This was done to aid in the finding of a consensus age. If a consensus age was not reached, due to the non-readability, the otolith was rejected and the second otolith, if present, was prepared as stated above. For this study ages were represented by the inland years; the hyaline center, sea years, were not counted for age determination.

\section{Statistical analysis}

Initially I conducted a Chi-square test of the null hypothesis that American eels were randomly selecting substrate types in proportion to availability (Manly et al. 2002). This test determined whether there was a significant difference between the expected use of substrate types and the observed frequency of use (Neu et al. 1974; Byers et al. 1984; Manly et al. 2002). In my habitat use experiment, substrate types were available in equal proportions; hence, "substrate selection" was equivalent to "substrate preference" as defined by Johnson (1980). Following the initial Chi-square analysis, I fit multinomial logistic regression models (Hosmer and Lemeshow 2000; Agresti 2002; Manly et al. 2002) to the data, which examined the influence of explanatory variables on eel substrate selection. Models specified substrate selection as functions of trial, aquarium, TL, and age. However, use of explanatory variables resulted in a sparse dataset, owing to an absence of continuous age and length data within some aquarium and trial categories. Due to the sparseness of the data, I used two separate multinomial logistic regression models for the two data types (categorical and continuous). The first set of models 
specified the substrate selection as functions of trial and aquarium while the second set of models specified the substrate selection as functions of TL and age. The leaf pack substrate was used as the baseline category for both sets of models. Each of the equations modeled the logit, which was the $\log$ of the ratio of the probability of selection for a particular substrate and the probability of selection for the leaf pack substrate (baseline category). To evaluate models, I compared the difference in deviance $(2 * \max \log$-likelihood of the fitted model /max log-likelihood of the saturated model) between the saturated model and the fitted model. Model fit was assessed using deviance, which follows a chi-square distribution (Hosmer and Lemeshow 2000).

To determine if American eels selected for or against a certain substrate type, odds ratios were derived from the multinomial logistic regression model. Odds ratios are measures of association which range from zero to infinity, and require the designation of one category as a reference (Hosmer and Lemeshow 2000). An odds ratio was estimated for each substrate type, and leaf pack was used as the "baseline category." An odds ratio greater than one supports selection for a substrate type instead of leaf pack (baseline category), where as odds ratios less than one indicates selection against a substrate type instead of leaf pack. An odds ratio of one implies that the selected substrate is equally likely in both categories (Hosmer and Lemeshow 2000). To test the odds ratios, 95 percent confidence intervals were calculated. The odds ratios were considered significant if the intervals did not contain a value of one. All computations were conducted using Microsoft Excel (2007) and the R software (R Development Core Team 2009).

\section{Results}

At the completion of the 9 trials, 130 out of 135 individuals used a substrate type while the remaining five individuals did not use any of the substrates provided. These five individuals were removed from the data analysis. The American eels used in this study had a TL range of 
224-338 mm (mean 273 mm, SE 2.34; Figure 2.3). The American eel consensus ages ranged between 3-11 years (mean 6 years, SE 0.157; Figure 2.4). Thirteen of the 130 eel otoliths were deemed unreadable by both readers. The thirteen unreadable otoliths along with their associated lengths were also not used in the multinomial logistical regression analysis of substrate selection.

Comparing the multinomial logistic regression deviances of the different models suggested the trial and aquarium did not have a significantly discernible effect on the eel selection of a particular substrate type (Table 2.1). All models compared to the saturated model (maximum number of parameters) did not show a significant $p$-value $(\alpha=0.05)$ and allowed the data to be collapsed across aquaria and trial for further analysis.

Yellow-phase American eels did not use substrate at the expected ratio of $1 / 5\left(X^{2}=\right.$ $67.462 ; \mathrm{df}=4 ; \mathrm{p}<0.005)$. Of the five substrate types provided, leaf pack was used by 63 of 130 (48.5\%), cobble was used by 21 of $130(16.2 \%)$, silt/clay was used by 18 of 130 (13.8\%), gravel was used by 16 of 130 (12.3\%), and sand was least used by 12 of 130 (9.2\%; Table 2.2). Using leaf pack as the baseline category, the odds ratio of an eel choosing any of the other substrates was less than one indicating that selection of other substrates was not as likely as that of choosing leaf pack. The calculated $95 \%$ confidence intervals did not contain a value of one therefore the odds ratios were significant $(\alpha=0.05)$. The other substrate types (cobble, gravel, sand, and slit/clay) odds ratios were then compared to one another and I found no significant ( $\alpha$ $=0.05)$ ratios among them.

After collapsing the selection data across aquaria and trial, I examined substrate use as a function of length and age. Box plots did not visually depict differences in American eel lengths or ages among substrate categories (Figure 2.5; Figure 2.6). To test this, I modeled the length and age substrate selection data as continuous in the multinomial logistic regression model. The analysis of deviance, from the multinomial logistic regression, indicated that discarding any one 
of the TL and age covariates from the saturated model had no influence on the American eel substrate selection (Table 2.3).

\section{Discussion}

In this laboratory study, yellow-phase American eels selected leaf pack over other available benthic substrates. Although leaf pack was the preferred substrate, American eels also used cobble, gravel, sand, and silt/clay substrates. American eels have been categorized as habitat generalists (Helfman et al. 1987), which has been supported by field studies reporting a wide range of substrates, including mud, cobble, gravel, sand, and leaf pack (Tesch 1977; Ford and Mercer 1986; Meffe and Sheldon 1988; Strickland 2002; Goodwin and Angermeier 2003; Thomas 2006). Although my study also found that American eels use a wide range of substrates, leaf pack selection provides evidence for preference of a specific benthic substrate when multiple habitat types are equally available.

American eels avoid sunlight through use of benthic substrates as burrow or refuge habitat during daytime, but also likely benefit from reduced predation risk, or increased foraging opportunities. Benthic substrates are important to yellow-phase American eels as refugia from predators (Tesch 1977; Fahay 1978; Facey and Van Den Avyle 1987). In some species, predation risk is likely reduced in substrates with adequate interstitial spaces (Stein and Magnuson 1976; Sponaugle and Lawton 1990; McAdam 2011; Smith et al. 2012). Although interstitial space is present in non-compacted leaf pack habitat, its importance to the selection of leaf pack habitat in our study is unknown. American eels, however, have the ability to burrow into small-sized substrates, such as silt/clay, sand, and gravel, as well as take refuge in substrates with larger interstitial spaces, such as leaf pack and cobble habitat. Availability of preferred habitat may reduce predation risk, because individuals may remain in that habitat for longer periods of time 
and spend less time exposed to predators while searching for suitable habitat (Smith et al. 2012). Although American eels are often nocturnal foragers, food availability within benthic substrates may also influence diurnal habitat selection. Diets of small American eels consist of bottom dwelling invertebrate larvae such as Ephemeroptera, Megaloptera, and Trichoptera (Ogden 1970; Tesch 1977; Facey and LaBar 1981). Leaf packs are considered "hot spots" for invertebrate activity because they provide both substratum and nutritional resources (Hershey and Lamberti 1998). Although prey items were removed from substrates in my study, American eels may have selected leaf pack habitat because of an expectation of higher prey availability.

By using a laboratory environment, I was able to control for some of the possible biological, physical, and chemical influences that could affect the probability of selection. Microhabitat selection in riverine habitat is more complicated than that represented in this controlled laboratory study, owing to other factors such as predation and food availability as previously discussed, as well as water depth and velocity, water quality, and intraspecific and interspecific competition (Krausman 1999). With exception of silt/clay substrate, I separated substrates into single categories of cobble, gravel, sand, and leaf pack; however, substrate types are often intermixed in riverine habitat. I reduced intraspecific competition through use of only five individuals per aquarium. The experimental design insured each eel had free and equal access to all available substrate types. Results are conditional on the five experimental benthic substrates, although these substrates are present in many rivers within the North American range of the American eel.

Substrate types had equal availability during this study (a necessary design to document preference), but the availability of leaf packs may be spatially and temporally variable in aquatic systems. Leaf pack habitat occurs naturally in discrete patches. The availability of leaf pack habitat in rivers increases during late autumn and with distance upstream. During spring and 
summer periods of lower leaf pack availability, American eels may use a wider range of benthic substrates (Thomas 2006). Leaf pack availability is also influenced by anthropogenic factors including land use and habitat alteration, such as river channelization (Gregory et al. 1991; Schlosser 1991; Jones et al. 1999). Watershed development can reduce riparian zones and the amount of allochthonous leaves (Gregory et al. 1991; Schlosser 1991; Jones et al. 1999). River channelization removes spatial complexity and reduces structure, eddies, and slack water associated with leaf pack accumulation (Gregory et al. 1991; Schlosser 1991).

Studies have indicated that American eels use habitat differently based on body lengths (Tesch 1977; Ford and Mercer 1986; Meffe and Sheldon 1988). Size specific habitat selection also occurs in other anguillid species (Tesch 1977; Jellyman et al. 2003; Laffaille et al. 2003). Ford and Mercer (1986) found habitat segregation between larger and smaller American eels. During growth to larger sizes, individuals may shift from macroinvertebrate to piscivorous diets (Laffaille et al. 2003), which may be associated with shifts in habitat selection. My study did not support size-specific habitat use, although individuals had a relatively narrow size range. In addition to size, age also did not influence substrate use. Individuals with multiple lengths and ages were often burrowed in the same leaf pack substrate bin (Appendix 2.1; Appendix 2.2).

In conclusion, yellow-phase American eels (224-338 mm TL and 3-11 years in age) selected leaf pack microhabitat during the laboratory study. If laboratory-based results are transferable to habitat use of American eels in nature, then study results supports leaf pack as an important benthic habitat. Our understanding of habitat use of American eels has management and conservation implications, particularly if American eel population decline is associated with habitat loss and alterations (Castonguay et al. 1994; Haro et al. 2000). Simple laboratory studies on habitat use contribute to an increased understanding of ecological relationships (Morrison et al. 1992). 
Future studies could consider field validation of laboratory results, or address other questions associated with habitat selection, such as larger length distributions, intraspecific competition, and predation risk within preferred and non-preferred substrates. Intraspecific competition could be examined by using differing densities or body sizes of eels within the substrate selection experiment. Ford and Mercer (1986) suggested substrate selection is size specific due to segregation between larger and smaller American eels. To test for segregation, eels of larger and smaller body sizes could be released separately into aquaria with equally available substrates. Next, the large and small eels could be combined and released back into the aquaria with the same equally available substrates. Differences in habitat use between separate and combined sizes would support size-specific habitat segregation. Predation risk within preferred versus non-preferred substrates could be tested by releasing a known predator (e.g. bass, Micropterus spp.) along with American eels into aquaria that have different types of substrates. Some aquaria could have non-preferred substrates (i.e. sand) only while other aquaria could have preferred substrates (i.e. leaf pack), then survival rates could be compared among aquaria.

\section{Literature Cited}

Agresti, A. 2002. Categorical Data Analysis. 2nd edition. John Wiley and Sons, Hoboken, New Jersey.

ASMFC (Atlantic States Marine Fisheries Commission). 2000. Interstate fishery management plan for American eel (Anguilla rostrata). ASMFC, Fishery Management Report 36, Washington, D.C.

Avise, J. C., G. S. Helfman, N. C. Saunders, and L. S. Hales. 1986. Mitochondrial DNA differentiation in North Atlantic eels: population genetic consequences of an unusual life history pattern. Proceedings of the National Academy of Sciences of the United States of America, 83:4350-4354. 
Byers, C. R., R. K. Steinhorst, and P. R. Krausman. 1984. Clarification of a technique for analysis of utilization-availability data. Journal of Wildlife Management 48:1050-1053.

Casselman, J. M. 2003. Dynamics of resources of the American eel, Anguilla rostrata: declining abundance in the 1990s. Pages 255-274 in K. Aida, K. Tsukamoto, and K. Yamauchi, editors. Eel Biology. Springer-Verlag Tokyo.

Castonguay, M., P. V. Hudson, C. M. Couillard, M. J. Eckersley, J. D. Dutil, and G. Verreault. 1994. Why is recruitment of the American eel, Anguilla rostrata, declining in the St. Lawrence River and Gulf? Canadian Journal of Fisheries and Aquatic Sciences 51:479488.

Facey, D. E. and M. J. Van Den Avyle. 1987. Species profiles: life histories and environmental requirements of coastal fishes and invertebrates (north Atlantic): American eel. U.S. Fish and Wildlife Service Biological Report 82(11.74). U.S. Army Corps of Engineers, TR EL-82-4.

Fahay, M. P. 1978. Biological and fisheries data on American eel, Anguilla rostrata (LeSueur). Technical Series Report No. 17. National Marine Fisheries Service, NOAA, Highlands, New Jersey.

Ford, T. E. and E. Mercer. 1986. Density, size distribution, and home range of American eels, Anguilla rostrata, in a Massachusetts salt marsh. Environmental Biology of Fishes 17:309-314.

Fretwell, S. D. and H. L. Lucas, Jr. 1970. On territorial behavior and other factors influencing habitat distribution in birds. I. Theoretical development. Acta Biotheoretica 19:16-36.

Glova, G. J. 1999. Cover preference tests of juvenile shortfinned eels (Anguilla australis) and longfinned eels (A. dieffenbachii) in replicate channels. New Zealand Journal of Marine and Freshwater Research 33:193-204.

Goodwin, K. R. and P. L. Angermeier. 2003. Demographic characteristics of American eel in the Potomac River drainage, Virginia. Transactions of the American Fisheries Society 132:524-535.

Gregory, S. V., F. J. Swanson, W. A. McKee, and K. W. Cummins. 1991. An ecosystem perspective of riparian zones. BioScience 41:540-551. 
Haro, A. J., W. Richkus, K. Whalen, A. Hoar, W. D. Busch, S. Lary, T. Brush, and D. Dixon. 2000. Population decline of the American eel: implications for research and management. Fisheries 25(9):7-16.

Hedger, R. D., J. J. Dodson, D. Hatin, F. Caron, and D. Fournier. 2010. River and estuary movements of yellow-stage American eels Anguilla rostrata, using a hydrophone array. Journal of Fish Biology 76:1294-1311.

Helfman, G. S., D. E. Facey, L. S. Hales, and E. L. Bozeman. 1987. Reproductive ecology of the American eel. American Fisheries Society Symposium. 1:42-56.

Hershey, A. E. and G. A. Lamberti. 1998. Stream macroinvertebrate communities. Pages 165195 In R. J. Naiman and R. E. Bilby, editors. River Ecology and Management. Springer, New York.

Hosmer, D. W. and S. Lemeshow, S. 2000. Applied logistic regression. John Wiley and Sons, Hoboken, New Jersey.

Jellyman, D. J., M. L. Bonnett, and J. R. E. Sykes. 2003. Contrasting use of daytime habitat by two species of freshwater eel Anguilla ssp. in New Zealand Rivers. Pages 63-78 in D. A. Dixon, editor. Biology, Management, and Protection of Catadromous Eels. American Fisheries Society, Symposium 33, Bethesda, Maryland.

Johnson, D. H. 1980. The comparison of usage and availability measurements for evaluating resource preference. Ecology 61:65-71.

Jones, E. B. D., III, G. S. Helfman, J. O. Harper, and P. V. Bolstad. 1999. Effects of riparian forest removal on fish assemblages in southern Appalachian streams. Conservation Biology 13:1454-1465.

Krausman, P. R. 1999. Some basic principles of habitat use. Pages 85-90 in K.L. Launchbaugh, K.D. Sander, and J.C. Mosley, editors. Grazing Behavior of Livestock and Wildlife. Idaho Forest, Wildlife and Range Experimental Station bulletin 70, University of Idaho, Moscow.

Laffaille, P., E. Feunteun, A. Baisez, T. Robinet, A. Acou, A. Legault, and S. Lek. 2003. Spatial organisation of European eel Anguilla anguilla in a small catchment. Ecology of Freshwater Fish 12:254-264. 
Liew, P. K. L. 1974. Age determination of American eels based on the structure of their otoliths. Pages 124-136 in T. B. Bagenal, editor. The Aging of Fish. Unwin Brothers, Surrey, UK.

Manly, B. F. J., L. L. McDonald, D. L. Thomas, T. L. McDonald, and E. P. Erickson. 2002. Resource Selection by Animals: Statistical Design and Analysis of Field Studies. Second edition. Kluwer Academic Publishers, Dordrechut, Netherlands.

McAdam, S. O. 2011. Effects of substrate condition on habitat use and survival by white sturgeon (Acipenser transmontanus) larvae and potential implications for recruitment. Canadian Journal of Fisheries and Aquatic Sciences 68:812-822.

Meffe, G. K. and A. L. Sheldon. 1988. The influence of habitat structure on fish assemblage composition in southeastern blackwater streams. The American Midland Naturalist 120:225-240.

Morrison, M. L., B. G. Marcot, and R. W. Mannan. 1992. Wildlife-Habitat Relationships: Concepts and Applications. University of Wisconsin Press, Madison.

Morrison, W. E. and D. H. Secor. 2003. Demographic attributes of yellow-phase American eels (Anguilla rostrata) in the Hudson River estuary. Canadian Journal of Fisheries and Aquatic Sciences 60:1487-1501.

Neu, C. W., C. R. Byers, and J. M. Peek. 1974. A technique for analysis of utilizationavailability data. Journal of Wildlife Management 38:541-545.

Ogden, J. C. 1970. Relative abundance, food habits, and age of the American eel, Anguilla rostrata LeSueur in certain New Jersey streams. Transactions of the American Fisheries Society 99:54-59.

Oliveira, K. 1996. Field validation of annular growth rings in the American eel, Anguilla rostrata, using tetracycline-marked otoliths. U.S. National Marine Fisheries Service Fishery Bulletin 94:186-189.

Oliveira, K. 1999. Life history characteristics and strategies of the American eel, Anguilla rostrata. Canadian Journal of Fisheries and Aquatic Sciences 56:795-802. 
R Development Core Team. 2009. R: A language and environment for statistical computing. R Foundation for Statistical Computing, Vienna, Austria. Available: http://www.Rproject.org (August 2011).

Rosenzweig, M. L. 1981. A theory of habitat selection. Ecology 62:327-335.

Schlosser, I. J. 1991. Stream fish ecology: a landscape perspective. BioScience 41:704-712.

Silberschneider, V., B. C. Pease and D. J. Booth. 2004. Estuarine habitat preferences of Anguilla australis and $A$. reinhardtii glass eels as inferred from laboratory experiments. Environmental Biology of Fishes 71:395-402.

Smith, D. M, S. A. Welsh, and P. J. Turk. 2012. Available benthic habitat type may influence predation risk in larval lampreys. Ecology of Freshwater Fish 21(1):160-163.

Smogor, R. A., P. L. Angermeier, and C. K. Gaylord. 1995. Distribution and abundance of American eels in Virginia streams: tests of null models across spatial scales. Transactions of the American Fisheries Society 124:789-803.

Sponaugle, S. and P. Lawton. 1990. Portunid crab predation on juvenile hard clams: effects of substrate type and prey density. Marine Ecology Progress Series 67:43-53.

Stein, R. A. and J. J. Magnuson. 1976. Behavioral Response of Crayfish to a Fish Predator. Ecology 57(4):751-761.

Strickland, P. A. 2002. American eel distribution and growth in selected tributaries of the James River. Master's thesis. Virginia Polytechnic Institute and State University, Blacksburg.

Tesch, F. W. 1977. The Eel. Biology and Management of Anguillid Eels. Chapman and Hall, London.

Thomas, J. 2006. American eel behavioral patterns in Silver Lake, Dover, Delaware. Master's thesis. Delaware State University, Dover.

Wentworth, C. K. 1922. A scale of grade and class terms for clastic sediments. The Journal of Geology 30:377-392.

WVU-ACUC (West Virginia University Animal Care and Use Committee). 2011. West Virginia University animal care and use committee aquatic animal husbandry and care standard 
operating protocol. Office of Research Integrity and Compliance, Morgantown, West Virginia.

Wiley, D., R. P. Morgan, and R. H. Hilderbrand. 2004. Relations between physical habitat and American eel abundance in five river basins in Maryland. Transactions of the American Fisheries Society 133:515-526.

Zimmerman, J. L. and S. A. Welsh. 2008. PIT tag retention in small (205-370 mm) American eels, Anguilla rostrata. Proceedings of the West Virginia Academy of Science 79(2):1-8. 

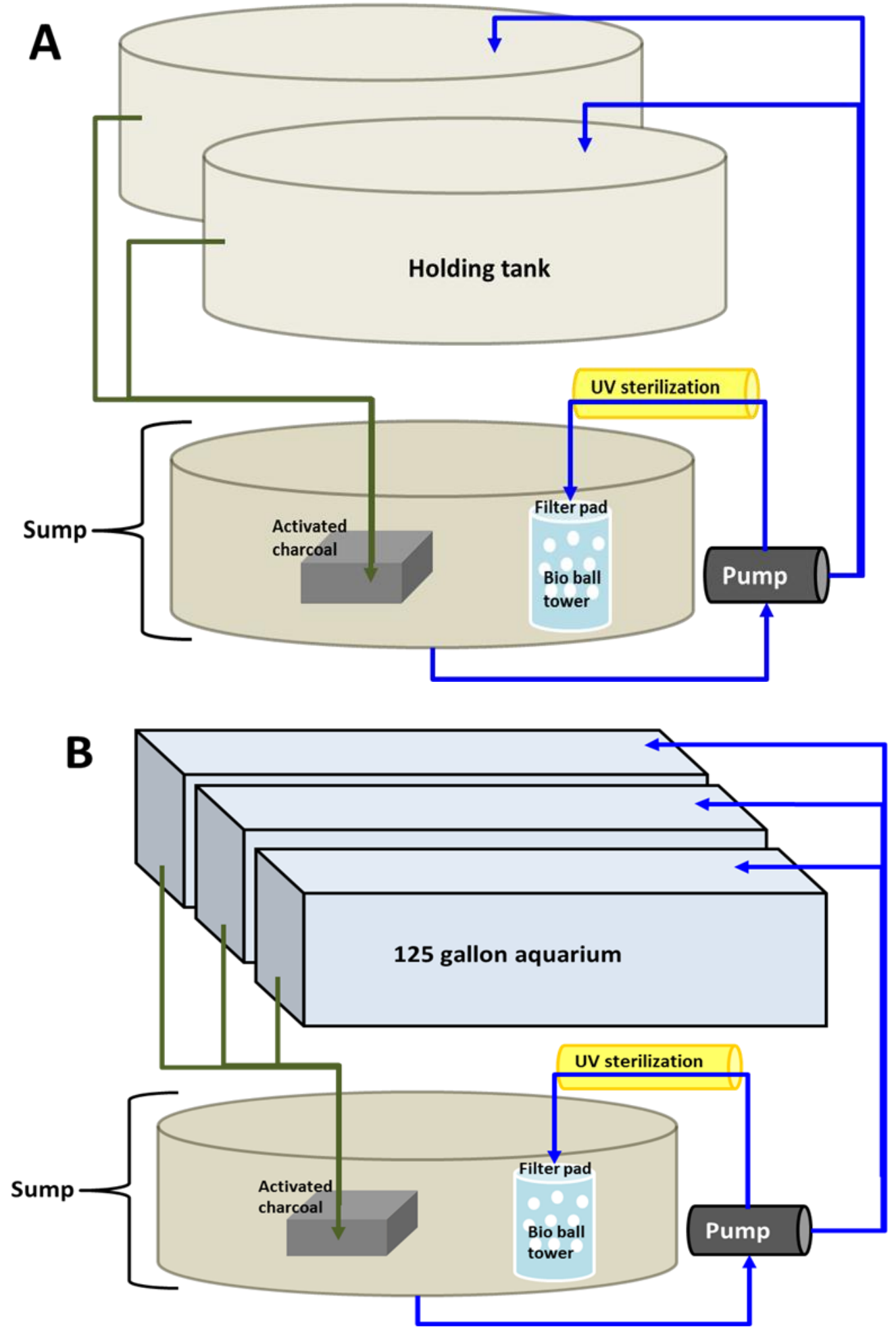

Figure 2.1. Diagram of recirculation system design for the holding tank system (A) and the substrate experiment system (B). 

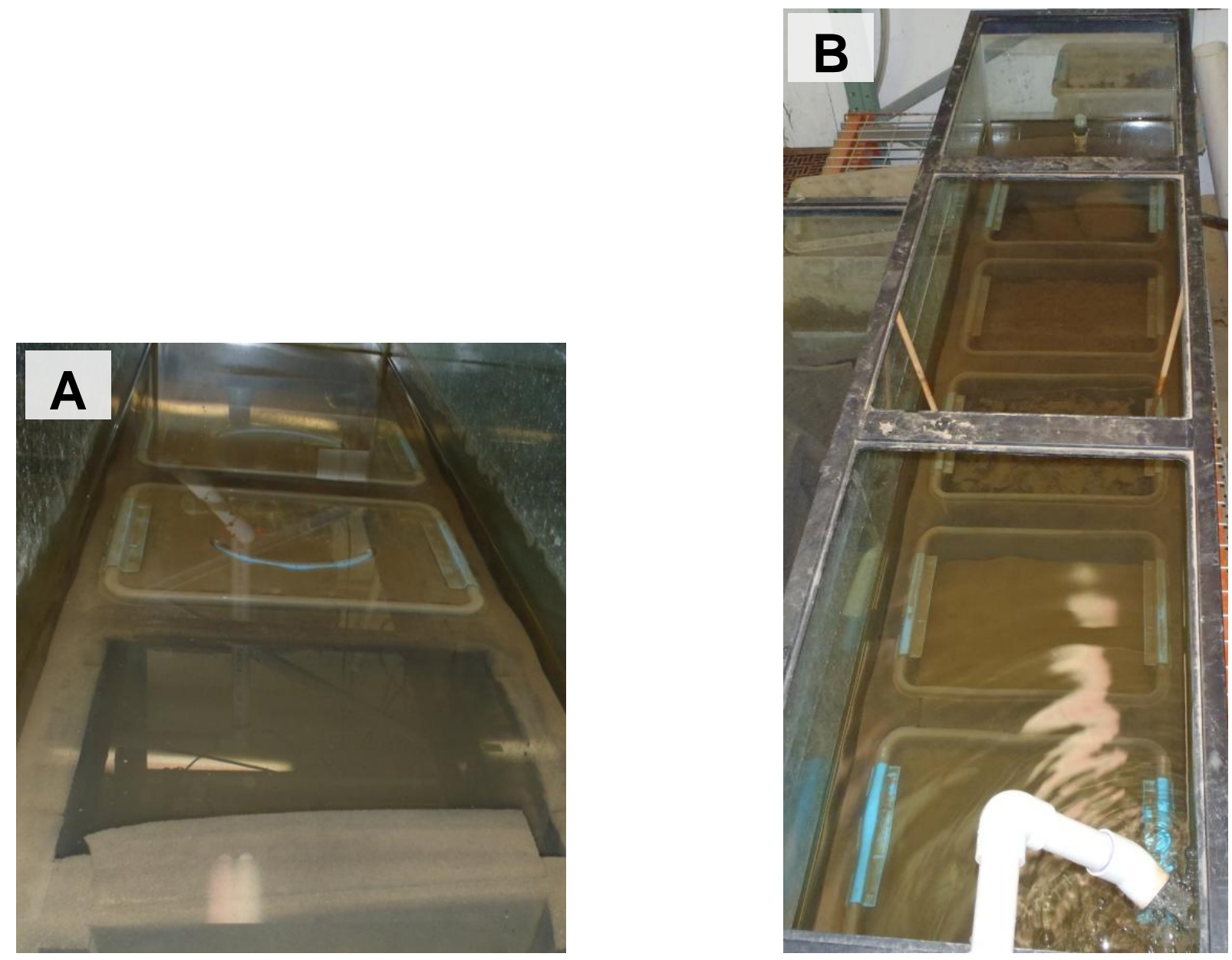

Figure 2.2. Photograph A shows the aquarium setup with one substrate bin removed to show fish friendly foam in place. Photograph B is the aquarium setup with substrate bins and fish friendly foam. Note the leaf pack substrate bin is being held in place by two wooden dowels. 


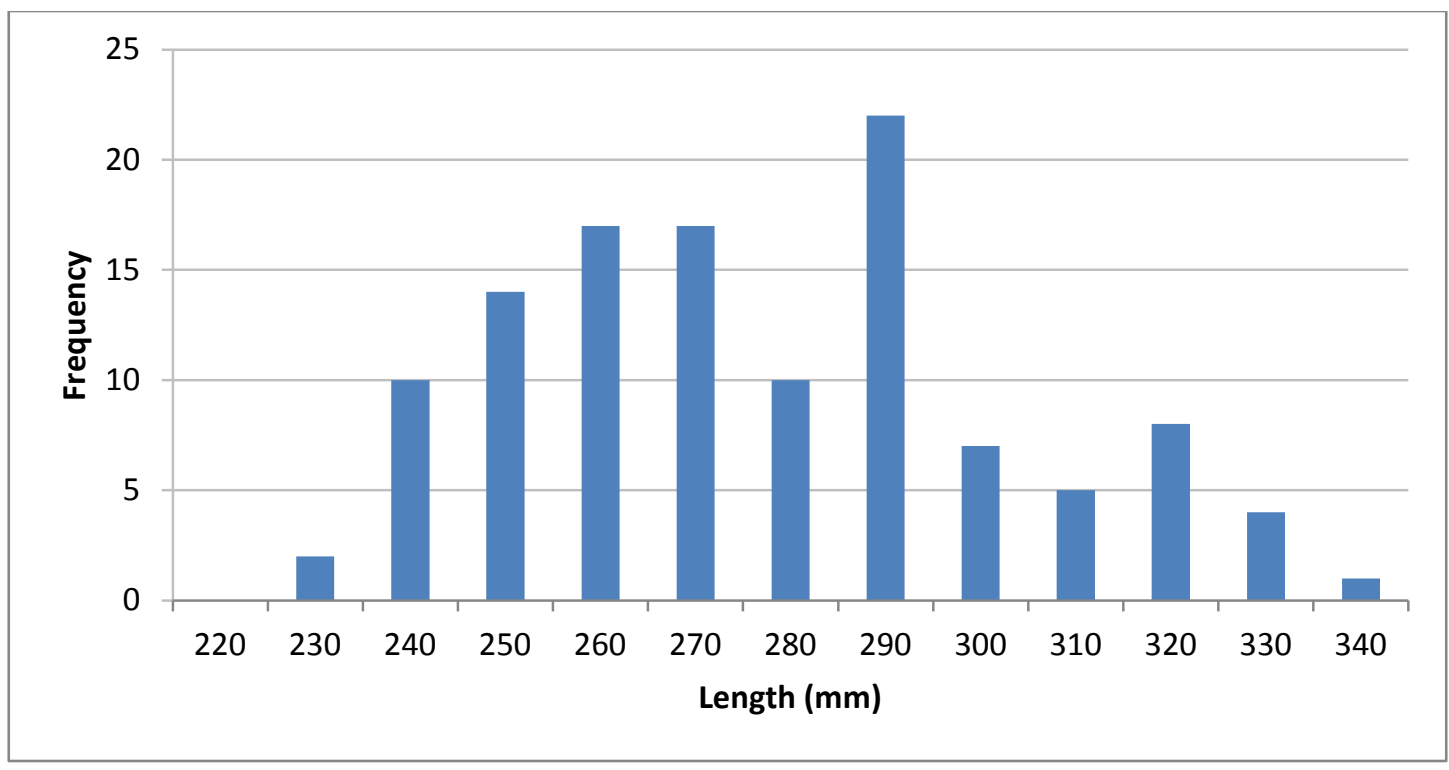

Figure 2.3. Length frequencies of 117 eels collected at the Millville Dam eel ladder and used during the substrate selection laboratory study. Lengths ranged from 224 to $338 \mathrm{~mm}$ (mean $=273 \mathrm{~mm}$, standard error $=2.34)$. Length categories are $10 \mathrm{~mm}$ intervals (e.g. the 230 length category represents eel lengths from 221 to $230 \mathrm{~mm}$ ).

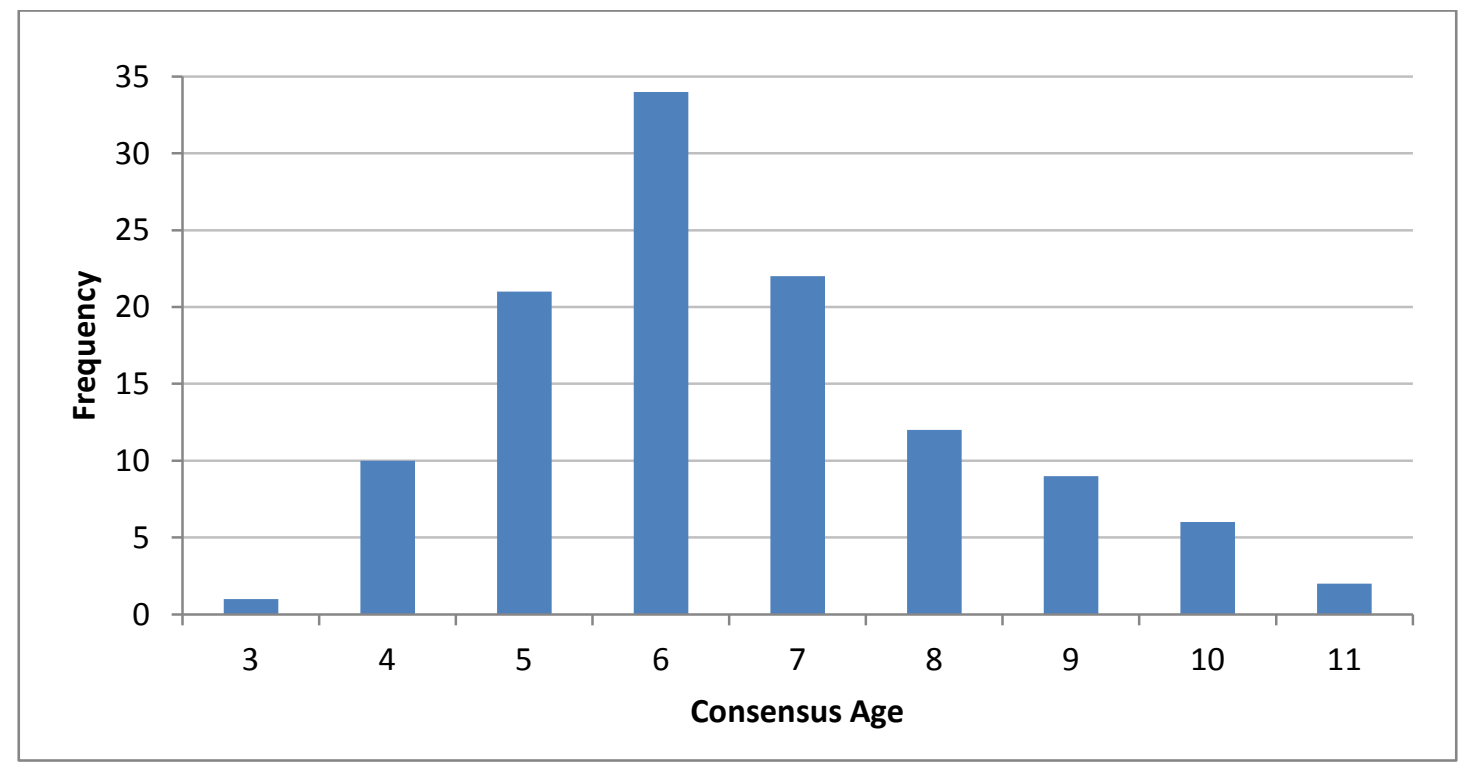

Figure 2.4. Consensus age frequencies of 117 eels collected at the Millville Dam eel ladder and used during the substrate selection laboratory study. The consensus ages ranged from 3 to 11 years $($ mean $=6$ years, standard error $=$ $0.157)$. 


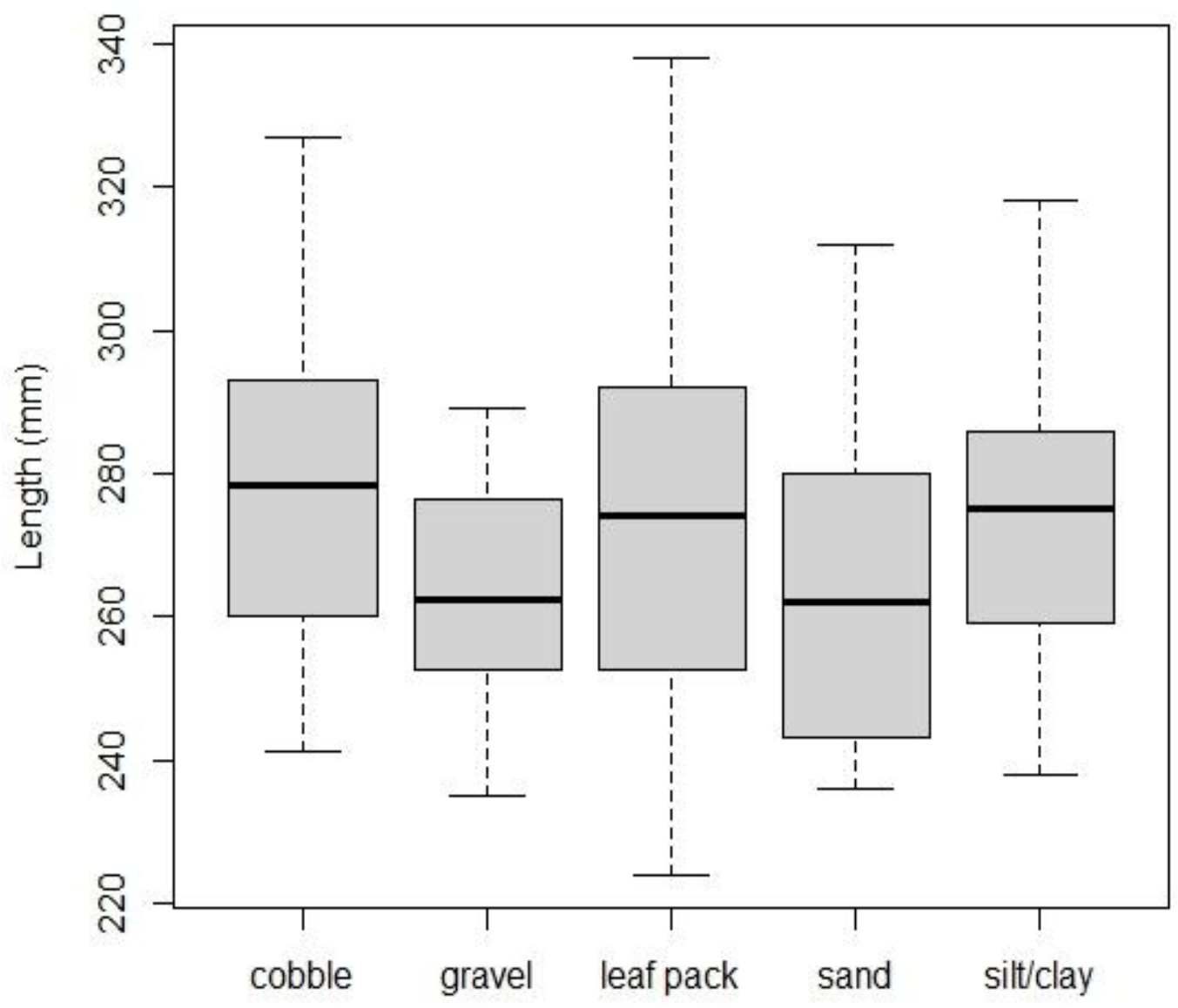

Figure 2.5. Box plot depicting the American eel use of five equally available substrate types as a function of total length $(\mathrm{mm})$. Bolded lines within the grey boxes are the median values, the grey boxes represent lower and upper quartile values, and the ends of the dotted lines represent maximum and minimal values. Lengths ranged from 224 to $338 \mathrm{~mm}(\mathrm{n}=117$, mean $=273 \mathrm{~mm}$, standard error $=2.34)$. 


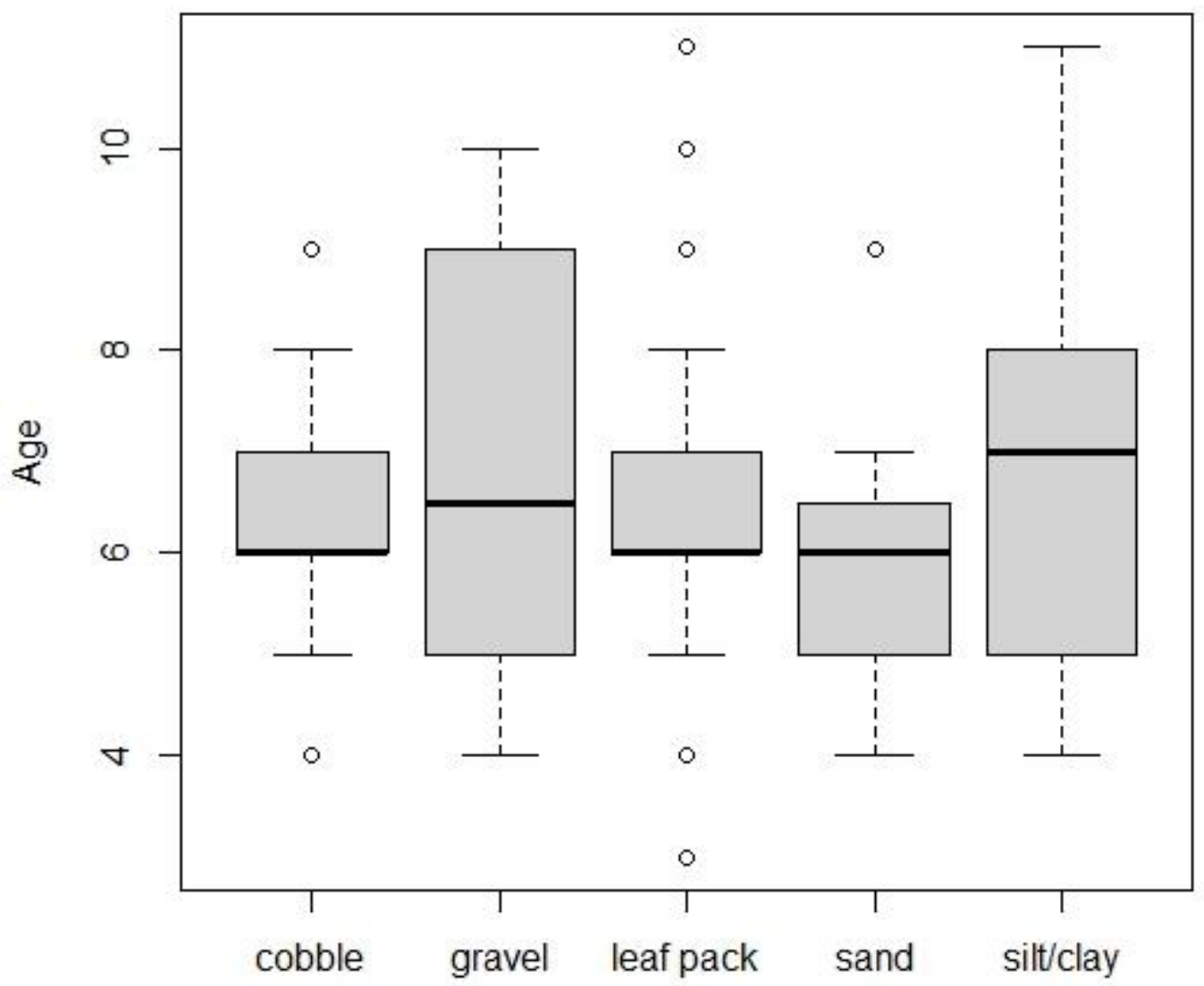

Figure 2.6. Box plot depicting American eel use of five equally available substrate types as a function of age. Bold lines within grey boxes are median values, grey boxes represent lower and upper quartile values, ends of dotted lines represent maximum and minimal values, and open circles represent outliers. Consensus ages ranged from 3 to 11 years $(n=117$, mean $=6$ years, standard error $=0.16)$. 
Table 2.1. Deviance statistics from a multinomial logistic regression analysis assessing the influence of aquarium and trial categories on substrate selection by American eels.

\begin{tabular}{rcccc}
\hline & Df & Deviance & LR $\left(\mathrm{G}^{2}\right)$ & P-value \\
\hline Saturated & --- & --- & --- & -- \\
Null & 104 & 363.24 & 105.21 & 0.448 \\
Aquarium & 96 & 358.67 & 100.64 & 0.353 \\
Trial & 72 & 318.02 & 59.99 & 0.843 \\
Aquarium + Trial & 64 & 313.08 & 55.05 & 0.780 \\
\hline
\end{tabular}

Table 2.2. Total number and percentage of yellow-phase American eel selecting each substrate. Odds ratios, standard errors (SE), and 95 \% Confidence Intervals (CI) for eel substrate selection of leaf pack versus all others.

\begin{tabular}{lcccccc}
\hline Substrate type & \# of eels & \% of eels & odds ratio & SE & \multicolumn{2}{c}{$95 \% \mathrm{Cl}$} \\
\hline Leaf pack & 63 & 48.5 & 1.00 & --- & -- & -- \\
Cobble & 21 & 16.2 & 0.33 & 0.252 & 0.203 & 0.546 \\
Gravel & 16 & 12.3 & 0.25 & 0.280 & 0.147 & 0.440 \\
Sand & 12 & 9.2 & 0.19 & 0.315 & 0.103 & 0.353 \\
Silt/clay & 18 & 13.8 & 0.29 & 0.267 & 0.169 & 0.482 \\
\hline
\end{tabular}

Table 2.3. Deviance statistics from a multinomial logistic regression analysis assessing the influence of age and total length covariates on substrate selection by American eels.

\begin{tabular}{rcccc}
\hline & Df & Deviance & LR $\left(G^{2}\right)$ & P-value \\
\hline Saturated & --- & --- & --- & --- \\
Null & 12 & 331.68 & 14.50 & 0.270 \\
Age & 8 & 324.78 & 7.59 & 0.474 \\
Total length & 8 & 326.20 & 9.01 & 0.342 \\
Age + Total length & 4 & 319.04 & 1.85 & 0.763 \\
\hline
\end{tabular}




\section{Appendix}

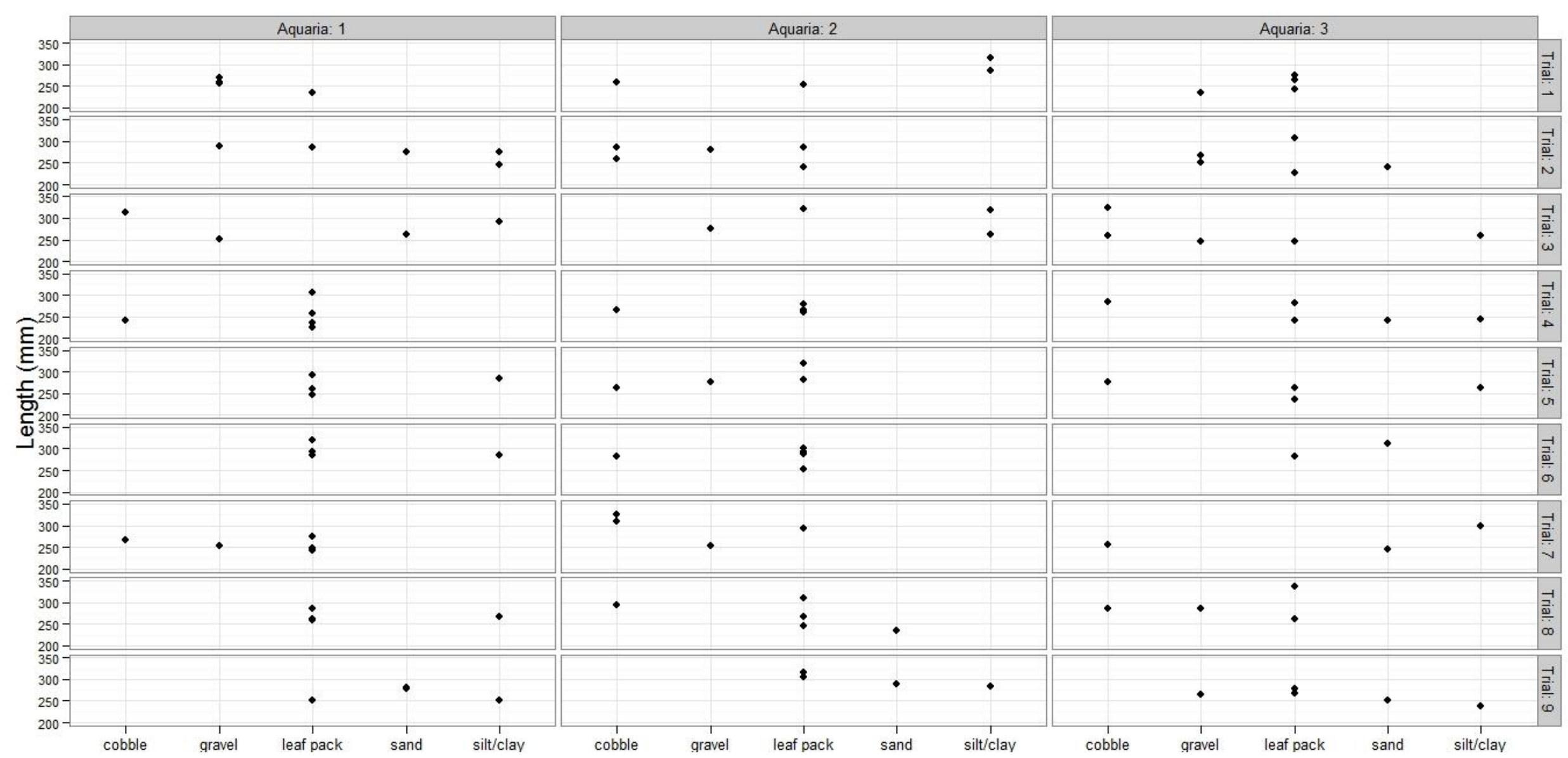

Appendix 2.1. American eel substrate selection of the five equally available types provided as a function of total length $(\mathrm{mm})$, by aquaria $(\mathrm{n}=3)$ and trial $(\mathrm{n}=9)$. 


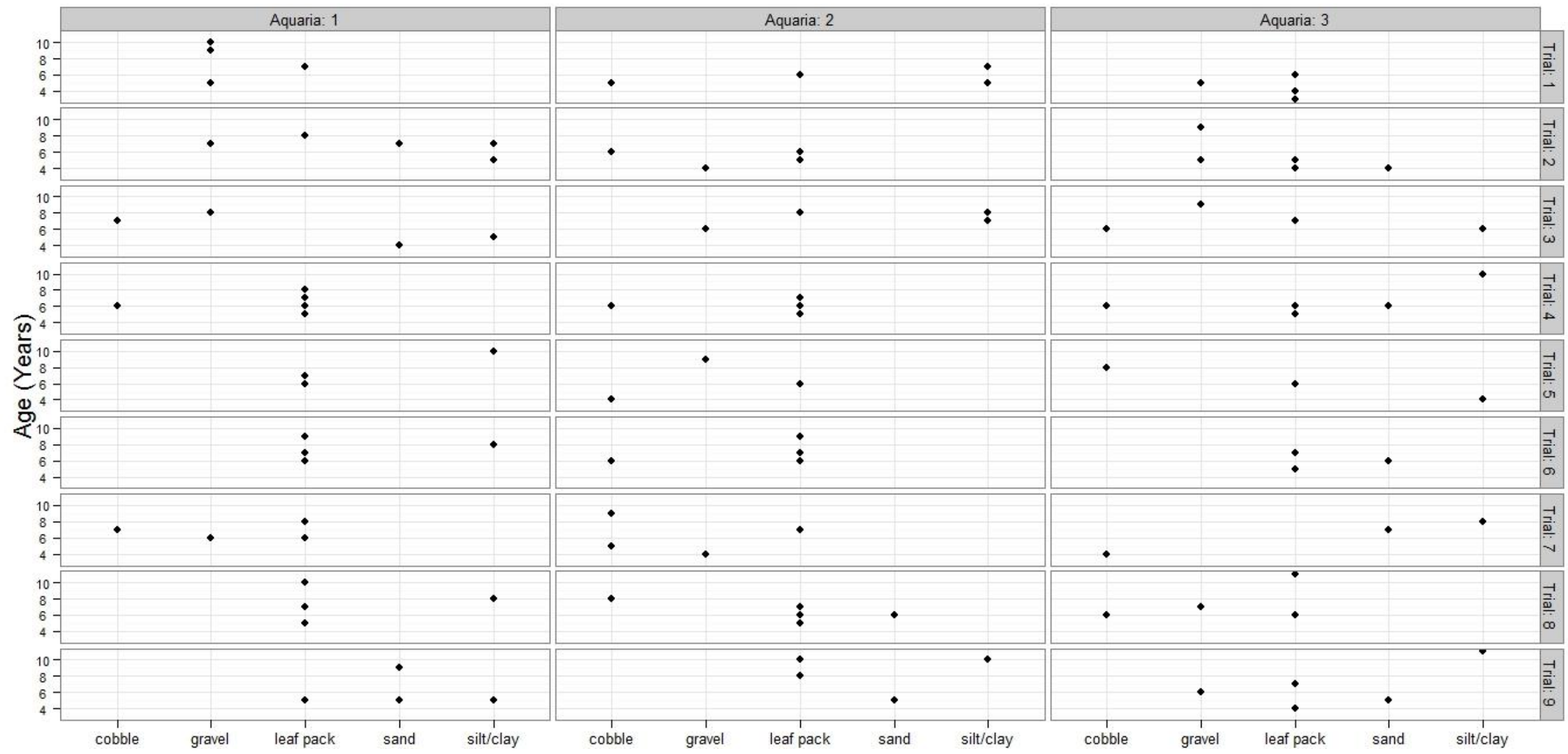

Appendix 2.2. American eel substrate selection data of the five equally available types provided as a function of total age, by aquaria $(n=3)$ and trial $(n=9)$. 